Postprint of published paper:

$\mathrm{Hu}, \mathrm{Di}$, and Kylie E. Quave. 2020. "Prosperity and Prestige: Archaeological Realities of Unfree Laborers under Inka Imperialism." Journal of Anthropological Archaeology 59 (September): 101201. https://doi.org/10.1016/j.jaa.2020.101201.

Associated data are published here: https://data.mendeley.com/datasets/fttj9mcw2h/3

\title{
Prosperity and prestige: Archaeological realities of unfree laborers under Inka imperialism
}

Di Hu${ }^{1}$

Kylie E. Quave² (corresponding author)

\begin{abstract}
Inka imperial policies reorganized the social and labor landscapes of their subjects on a grand scale and unprecedented degree in the Americas. The two most numerous categories of resettled laborers created by these imperial policies were the mitmaqkuna and yanakuna, who together represented at least a third of the total subject population. The Inkas resettled them, often far from their homelands. They were responsible for the daily provisioning of Inka settlements and keeping the peace among conquered populations. Despite their central role in Inka state consolidation and economy, we know little about these populations outside of ethnohistorical interpretations of their privileged status relative to normal tribute-paying communities. Because ethnohistoric documents were written with Inka and Spanish state interests in mind, archaeological evidence is crucial to evaluate their lived experiences. We compare the ethnohistoric and archaeological evidence of the lives of the mitmaqkuna and yanakuna in two regions: the mitmaqkuna site of Yanawilka in the Vilcas Huamán province and the yanakuna site of Cheqoq in the rural Inka heartland of Cuzco. Archaeological comparisons yield evidence contradicting the long-held assumption that prestige is synonymous with autonomy, power, or even wealth in imperial contexts.
\end{abstract}

Key words: Inka empire, state consolidation, imperial policies, inequality, mitmaqkuna, yanakuna, coerced labor, household archaeology, resettlement

\footnotetext{
1 James Madison University, 71 Alumnae Dr, Harrisonburg, VA 22801, United States. hudx@jmu.edu

2 The George Washington University, 2100 Foxhall Rd NW, Washington, DC 20007, United States. kquave@gwu.edu
} 


\section{Introduction}

A common refrain of state narratives, ancient and modern, is that the state civilizes its subjects, giving them peaceful and privileged lifestyles that those outside of "civilization" do not enjoy (Scott, 2017). Contradicting these narratives, archaeological research has shown that, up to very recently, the vast majority of people living under states suffered from want, fear, disease and heavy labor (e.g., Croucher, 2015; Klaus and Tam, 2009; McGuire and Reckner, 2002; Moore, 1989; Scott, 2009, 2017: 31; Sironi, 2019; Yoffee, 2005). Why have people historically endured the poor quality of life experienced under state control? One popular line of thinking is that state coercion and the threat of violence prevented people from freely leaving, just as the mafia punish those who desire to leave their "protection" (Miller and Tilley, 1984; Scott, 2009, Tilly, 1985). What this line of reasoning overlooks are the value-based strategies states use to keep populations captive. Most people remained under state control for reasons other than fear of violent punishment. The poorest subjects of the state often defended the same structures that kept them poor as long as they had access to other forms of social prestige (e.g., Armengol, 2017; Garnsey and Woolf, 1989; Howson, 1990; O'Toole, 2012; Robinson, 2000; Scott, 1985; Tutino, 2011: 24; Woolf 1997, 2000, 2012: 82-85).

Using the Inka Empire as a case study, we argue that the creation of value systems of prestige and the formation of unfree laborers went hand-in-hand in imperial state consolidation. Written sources do not record any instance of mitmaqkuna or yanakuna rebelling against their Inka overseers, unlike the numerous incidents of rebellion by normal subject populations. To induce fealty, the Inka controlled and strategically distributed the trappings of prestige among their subjects (Costin, 2018). The privileges that the Inka supposedly gave the mitmaqkuna and yanakuna were a combination of material benefits, such as luxury prestige goods, and social benefits, such as increased freedoms (Cieza de León, 1959: 57-59, 60-61; Cobo, 1979: 190; Sarmiento de Gamboa, 2010: 146).

If the ethnohistorical sources are to be believed, the mitmaqkuna and yanakuna should theoretically be more prosperous than normal subject communities (Rowe, 1982; Yaya, 2015). Because the historical record was based on elite Inka and Spanish perspectives, archaeological investigation is necessary to assess whether these two classes of people were privileged and to determine what kinds of privileges they enjoyed, if any. We show that, as a whole, the mitmaqkuna and yanakuna experienced lower indices of overall material wealth and autonomy than the normal subject communities. Our case studies include the agricultural mitmaqkuna settlement called Yanawilka in Vilcas Huamán and the yanakuna settlement called Cheqoq in rural Cuzco (Figure 1). 

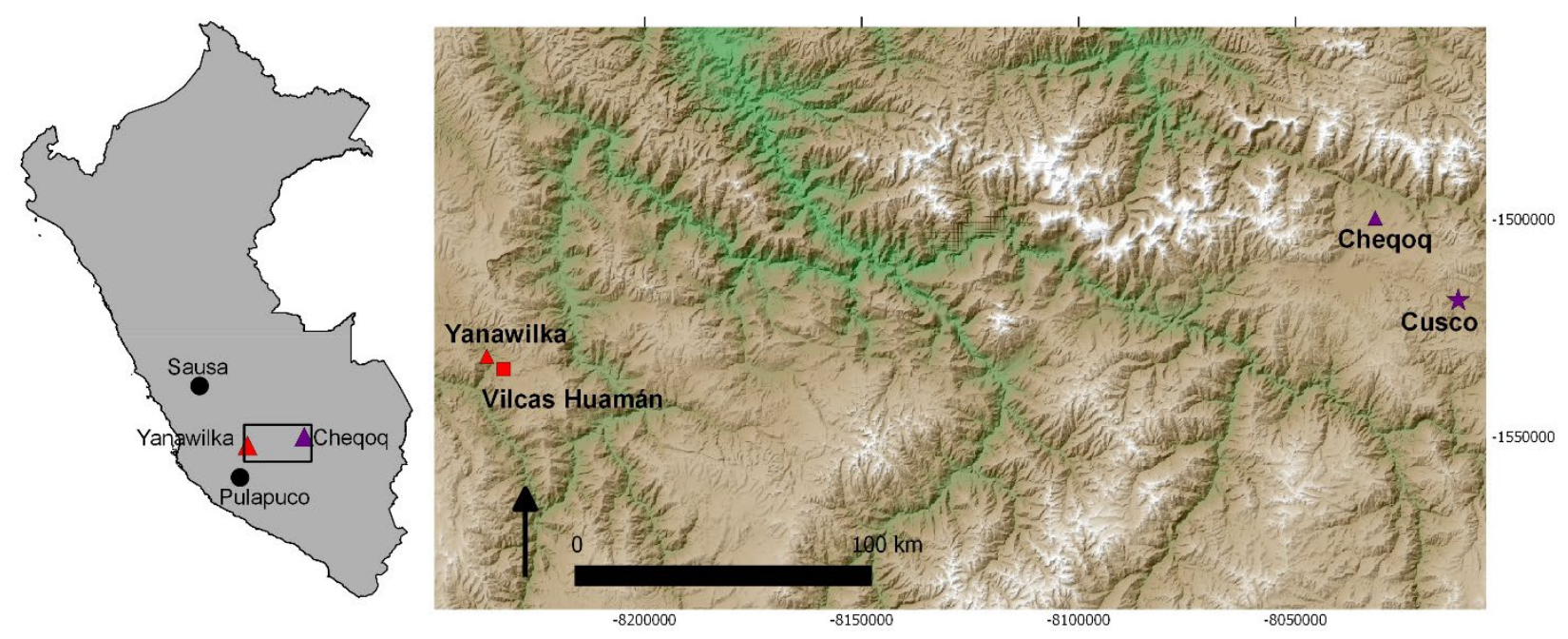

Figure 1. Map of sites mentioned in text. Figure by Quave and Hu, 2020; available at http://dx.doi.org/10.17632/fttj9mcw2h.3 under a CC-BY4.0 license.

The mitmaqkuna were ethnically non-Inka peoples resettled by the Inka to secure rebellious areas, and to craft and farm for the state (D'Altroy, 2005; Espinoza, 1970, 1973, 1983; Gyarmati and Condarco, 2018; Lorandi, 1984; Wachtel, 1982). The yanakuna, like the mitmaqkuna, were ethnically non-Inka peoples who were resettled into new communities near Inka settlements to serve as retainers who attended to the daily needs of the Inka (Dunbar, 1950; Niles, 1993; Turner et al., 2009; Villar, 1966). The primary difference between mitmaqkuna and yanakuna is that the former were resettled temporarily and expected to return to their natal provinces as tribute-paying subjects, while the latter were removed from their home provinces permanently. Though there is agreement they were removed from their homelands, some historians treat the yanakuna as a type of "Inka of privilege" (Segalini, 2017; Villar, 1966; Yaya, 2015). Likewise, the mitmaqkuna have been described to have been "so honored and valued by the Incas that they considered them, after the Orejones [the Inka class], the highest nobility of the provinces" (Cieza de León, 1959[1533-34]: 59). Mitmaqkuna and yanakuna differed from the normal subject populations, the suyuruna, who remained in their communities and gave corvée labor tax and tributary goods tax (D'Altroy, 2005; Rowe, 1982).

In the historic literature, the yanakuna have been treated as a subgroup of mitmaqkuna such as in the analysis by Rowe, whose interpretation of these groups is most widely cited to date (Rowe 1982). Such grouping of the two distinct categories masks important differences. To be separated from one's homeland temporarily would produce different outcomes than permanent, multigenerational alienation through resettlement. We find another aspect of the historical reading of these laborers to be lacking: according to the ethnohistorical record, the Inka masterfully doled out privileges and prestige items to secure the loyalty of their subjects (Cieza de León, 1883[1518-1554]: 37; Cobo, 1979[1653]: 190; Costin, 2018). We ask, however, whether there were actually multiple strategies of distributing privilege from the empire to its subjects. If so, we predict that each strategy gave rise to and reinforced specific categories of laborers. By comparing the mitmaqkuna and yanakuna to the normal subject population (those 
not obliged to resettle), we analyze the spectrum of exclusion from Inka-sponsored prosperity and prestige. We anticipate that perhaps the yanakuna retainers enjoyed more trappings of Inka-provided prestige than the temporarily resettled mitmaqkuna.

Another theme of this study is assessing the impacts that unfree laborers had on imperial political economy. Scholars have hypothesized that over time, the proliferation of production enclaves staffed by retainers (yanakuna) and occupationally-specialized, temporarily resettled laborers (mitmaqkuna) made corvée labor an increasingly smaller proportion of the total labor in service of the Inka Empire (D'Altroy, 1992, 2001, 2005; Murra, 1980). This shift toward retainer and mitmaqkuna labor allowed the Inka to decrease their dependence on local political authority and consolidate control over subject labor (D'Altroy, 1992: 178). In one province, for example, the Inka emphasis on co-opting the host role traditional to the Sausa elite of the Upper Mantaro was expensive, as it relied on conspicuous generosity in feasts and giftgiving (D'Altroy and Hastorf, 2001). We test an implication of this hypothesis that state-created labor communities were less expensive to maintain and more politically stable than the corvée system, which relied on conspicuous generosity to maintain legitimacy. The corvée system was also more politically autonomous from the Inka, meaning community leaders and members theoretically could control more of their surplus labor. The economic implication is that statecreated labor communities may have been, as a whole, poorer than normal subject communities. Until now, no excavations of confirmed mitmaqkuna and yanakuna communities were available to test this hypothesis.

We show that the archaeological evidence paints a complex picture of prestige and wealth in the different types of subject communities of the Inka Empire. Rowe (1982: 97) assumed that "the more closely a person was identified with the government, the greater was his or her chance of attaining the rewards available in the system." We measure closeness to the Inka government through the proxy of affinity to Inka commensal practices, which reflected the degree of Inka-bestowed prestige. By comparing the degree of affinity to Inka commensal practices (ceramic forms and percent Inka imperial style) to indices of wealth or prosperity (artifact densities) in different kinds of communities (mitmaqkuna, yanakuna, and normal subject communities), we show that a greater degree of affinity to Inka commensal practices in a community did not necessarily mean that community had greater wealth. Thus, we put into question the assumption of prestige (status) and prosperity (wealth) among resettled groups in the Inka Empire and ask whether those features of status and wealth ought to be de-coupled rather than presumed to co-occur.

\section{Disconnecting prestige and prosperity in state contexts}

Intersectional Black feminist and Marxist thought explain how the creation of systems of oppression are intimately tied to the creation of systems of difference (Battle-Baptiste, 2011; Franklin, 2001; Matthews et al., 2002; Robinson, 2000). Difference is multiplied and formalized, creating a dizzying array of social identities that correspond to greater experiences of oppression or access to privilege (Cho et al., 2013; Cooper, 2016; Crenshaw, 1989, 1991). The creation of these systems of difference is through widespread participation of all social classes in the creation of imperial culture, and is not just directed by the elite (e.g., Voss, 2008). 
Black Marxist thought, influenced by Frederick Douglass $(2014,2018)$, W. E. B. Du Bois (1935, 1972), and Antonio Gramsci (1992), among others, seeks to explain the creation of value systems (i.e., "hegemonic culture") that make people, such as poor whites in the U.S. context, act against their own material interests by supporting slavery. The creation of "prestigious" identities can be used to divide class interests. The proliferation and formalization of social differences in state contexts allowed a small elite group to enjoy an ever greater concentration of economic resources as the non-elite vied with each other over increased access to social prestige, and not necessarily economic autonomy. Black Marxist thought also emphasized counter hegemonic narratives and consciousness. People were not dupes and often acted in ways that undermined the system while at the same time miming accommodation toward the ruling elite.

We propose that imperial states like the Inka became economic powerhouses when they de-coupled prestige from a good quality of life (prosperity) for their subjects. Within the Inka ruling class, different lineages politically vied with each other for power (Covey, 2006a; Rostworowski, 1999; Sabloff, 2019), which incentivized the creation of economically efficient ways to extract labor. They had to manage immense systems of wealth production for imperial expansion. Administering all these resources and attendant labor for the benefit of noble families and the administrative costs of the empire entailed the creation of complicated systems of difference for their subjects. These systems of difference reinforced the creation of unfree laborers that were less costly to maintain both economically and politically, even as they were supposedly more socially esteemed in the eyes of Inka society. Resettled laborers often brought new lands into production in underused areas (Covey, 2011) and likely required little state intervention to build needed domestic infrastructure, but they also were settled where there were already populations present. We have found expedient, non-standardized architectural constructions in our excavations. Furthermore, the domestic areas of mitmaqkuna and yanakuna have been notoriously difficult to identify archaeologically (Niles, 2004: 60), which we assume is due to a lack of elaborate constructions. We also argue that resettled laborers presented fewer risks of rebellion and noncompliance than regular tribute-paying communities: resettled populations did not require the same gift-giving and performed generosity, but they also were less likely to be able to rebel when separated from their homelands and their kin. Resettlement--temporary or permanent--ensured a degree of dependency on the state by separating people from each other and from their resources.

If prestige and quality of life were de-coupled in order to build Inka sociopolitical and economic hegemony, that should be reflected among populations that were forcibly resettled and made unfree through processes such as their removal from ancestral lands and their imposition in new social contexts in the service of others' interests. Therefore, the research questions guiding this comparative study are:

1. How was prestige enjoyed in these communities? How did resettled laborers work, dine, and interact with other communities and identities?

2. How do quality of life and prosperity compare in each forced resettlement context to the normal subject communities? What can the comparison tell us about the cross-cultural study of states and empires? 


\section{Ethnohistoric research on Inka labor categories}

While labor tribute can be identified archaeologically, the specific labor categories related to that tribute are more difficult to discern from the material record (e.g., Costin and Hagstrum, 1995). With rich ethnohistoric records providing regional and site-level context, we are able to identify different types of settlements with some confidence and, in turn, test the ethnohistoric expectations through the archaeological records of each type of settlement.

When the Inka state first began expansionist military campaigns outside the Cuzco heartland in the early fifteenth century, they had to reconquer the same areas repeatedly (Sarmiento de Gamboa, 2010[1572]: 119-120). The historical chronicles credit the mitmaq policy as the key to consolidating conquered territories. The mitmaq policy was reportedly invented by Inka emperor Pachakuti to solve the problem of the constant need for reconquests (Betanzos, 2015[1557]: Pt. 1, Ch. XVIII; Garcilaso de la Vega, 1989[1609]: 303; Polo de Ondegardo, 1873[1575]: 152-155; Sarmiento de Gamboa, 2010[1572]: 119-120, 146). A quarter to a third of the total subject population, or up to 5 million people, was composed of mitmaqkuna at the height of the Inka Empire (D'Altroy 2005: 265, 2014: 273). Informants trusted by the chronicler Juan de Betanzos described the mitmaqkuna as settlers from one province into another (2015, Pt. 1, Ch. XXVI). The mitmaq policy was intended to quell rebellious landscapes and provide a reliable and politically dependent labor force for the Inka. The divide-and-conquer mitmaq policy shuffled social landscapes, making them more politically fragmented, sowing suspicion among neighboring communities (Cieza de León, 1959[1533-34]: 57, 60-61; Cobo, 1979[1653]: 190-191; Toledo, 1882: 118).

The yanakuna were particularly associated with specific Inka royal factions and their royal estates. Ruling factions developed productive and recreational mosaics of resources during the rulers' lifetimes; those resources were subsequently held in perpetuity by the descendants of those noble lineages (see Covey, 2011; Niles, 2004; Quave, 2018). Estate components included storage complexes, herds and pastures, forests of timber and hunted species, pleasure gardens, irrigated and improved agricultural plots, coca fields, salt sources, and infrastructure such as bridges and towns of resettled laborers--first, the temporary mitmaqkuna and then permanent yanakuna (Niles, 1999, 2004; Rostworowski, 1970; Toledo, 1940; Villanueva, 1970). The mitmaqkuna and yanakuna included numerous specialist categories. On the royal estates, as in other labor colonies, 16th-century eyewitnesses reported that there were specific types of labor specialists in service, including salt mining, pottery making, farming, herding, and more (Falcón, 1918[1567]). With proliferating lineages and the need to sustain both the living and the dead, the Inka had to continually expand their extractive capabilities through increasing the number of mitmaqkuna and yanakuna.

Previous historically-based scholarship on the mitmaq and yana institutions interprets them as occupying privileged statuses. Rowe argued that the source of honor and privilege was the Inka government and proximity to it, which was a phenomenon he assigned to those of mitmaq and yana status (Rowe, 1982: 97). Rowe identified the nature of yanakuna status through the historic record, variously describing them as servants, disciples, persons providing service that "might be honorable and fully compatible with high status," and persons who were eligible for elevation to leadership positions (1982: 98-100). This conceptualization of the yanakuna as prestigious also emerged in Villar's 1966 description of the yanakuna; both 
scholars take their definitions from the chroniclers Sarmiento de Gamboa and Cabello Valboa, as well as the early colonial dictionary of Diego González Holguín. Villar's historical study defined the yanakuna as existing in a special social status between the nobility and the normal tributary classes and rejected scholarship suggesting greater affinities with enslaved populations (1966: 24; cf. Las Casas, 1948). The specific privileges cited for the yanakuna included proximity to the noble family (in terms of newly created social relationships, but also geographic proximity through estate service), as well as (sometimes) access to aqllakuna for marriage (Pizarro, 1891[1571]: 496-498). The specific privileges cited for the mitmaqkuna included access to fertile lands, clothing, jewelry, and women (Cieza de León, 1959[1533-34]: 60-61).

To the detriment of subject communities' local systems of labor, resettlement also redirected their labor toward particular Inka production enclaves. Wayna Qhapaq reportedly settled some 150,000 mitmaqkuna in the Yucay Valley temporarily, where they canalized the river, created agricultural fields, and set up recreational houses for the Inka ruler. Upon completion of this project, he permanently resettled mitmaqkuna from many lands and transferred their status to yanakuna (Betanzos, 2015[1557], Pt. 1, Ch. XLIII). The Yucay Valley estate complex included the economic installation and yanakuna settlement of Cheqoq, the home of the yanakuna analyzed in this study (Quave, 2018; Quave et al., 2013). Royal estates in the imperial heartland economy established and maintained wealth for royal factions and, in turn, financed the political ambitions and personal alliances of particular factions. The process of converting/intensifying heartland resources and staffing them with temporarily and permanently resettled laborers, however, had another important consequence: laborers had their energy extracted from them to benefit the nobility while also being removed from their home kin networks and losing certain everyday freedoms through obligatory resettlement. Did those laborers benefit in other tangible or conceptual ways? If so, were those benefits material to everyday prosperity in these communities?

\section{Archaeological background and test cases}

Researchers working in some Inka provinces have convincingly identified mitmaqkuna presence through excavations (Gyarmati and Condarco, 2018) or survey methods (Spurling, 1992) combined with documentary evidence. These projects have not focused on the household unit of these laborers. In the heartland, however, scholars of Inka royal estates believed there were no remaining physical traces of mitmaqkuna and yanakuna settlements (Niles, 1999: 60); many instead focused on the royal palaces and monumental sites there (Alcina, 1970; Farrington, 1995; Nair, 2015). Due to the last few decades of systematic regional surveys in the Cuzco region (Bauer, 2004; Covey, 2006b, 2014b; Covey and Amado, 2008; Covey et al., 2008; Kosiba and Bauer, 2013), it is now possible to identify yanakuna sites with archival links. The regional context is not as well developed in Vilcas Huamán province, but Hu's recent excavations provide insight into a well-documented mitmaqkuna settlement. 


\section{Mitmaqkuna settlement of Yanawilka}

Archaeological and historical investigation of a site near the Inka provincial capital of Vilcas Huamán called Yanawilka strongly support its status as a mitmaqkuna settlement (Hu and Shackley, 2018). First, Yanawilka was initially settled in the Inka Late Horizon (1400-1532 $\mathrm{CE})$ rather than being a pre-Inka site that continued to be inhabited. The oldest charcoal sample from Yanawilka, embedded in the floor of one of the structures (unit Y3), was dated to 1424$1439 \mathrm{CE}(1 \sigma$, IntCal13), consistent with the traditional beginning of Pachacuti's imperial expansion in 1438 (Rowe, 1945). Furthermore, diagnostic Inka ceramics were found underneath large foundation stones of one of the excavated structures (unit Y1), indicating the structure dated to after the beginning of the Inka Late Horizon. Second, Yanawilka lacked clear Inka architectural canon and settlement layout, indicating it was designed by people with non-Inka identities. With the exception of a small possible Inka-style structure, all structures at Yanawilka were non-Inka in style and lacked Inka-style masonry (Hu, 2019). Third, historical evidence indicates that Yanawilka was settled by mitmaqkuna from the Conde ethnic group (Hu, 2016: Appendix D; Piel, 1995). In the sixteenth century, Yanawilka was inside the boundaries of the Conde mitmaqkuna community of Vischongo, which supports Yanawilka being occupied by the same mitmaqkuna under Inka rule. In land titles, "Yanavilca" or Yanawilka is listed as one of the boundary markers of the former "patrimony of the Inkas" that the Condes subsequently claimed as their own due to traditional usufruct rights. Furthermore, the original inhabitants of Vilcas Huamán province were deported elsewhere to make room for mitmaqkuna groups (Carabajal, 1965[1586]), so Yanawilka, with its post Inka-conquest occupation, was probably a mitmaqkuna settlement. The only original inhabitants not deported were the Tanquihua, but because their Spanish colonial period communities were located far from Yanawilka, they were likely not its inhabitants.

\section{Yanakuna settlement site of Cheqoq}

The site of Cheqoq is located on the Maras Plain, about $20 \mathrm{~km}$ northwest of the city of Cuzco. At 22 ha, Cheqoq was the largest settlement in the Inka period in the Maras district, according to systematic survey in the region (Covey, 2014a: 155). It was also part of a significantly interrupted settlement system in which the Late Intermediate Period (ca. 10001450 , or the period preceding Inka imperial organization, henceforth "LIP") had been characterized by a hierarchical settlement pattern which was replaced in the imperial period by Cheqoq and another very large site, a few small villages of a few hectares, and mostly smaller sites of less than a hectare (Covey, 2014a: 155-157). This interruption in local settlement likely occurred in the late 15th century, as there is relatively little pottery at Cheqoq in the early Inka or Killke style (Quave, 2017: Table 2); Killke pottery can be used as a rough measure for preimperial and imperial chronologies in the Cuzco region (Bauer and Stanish, 1990). The regional survey and excavations demonstrate a late and dramatic shift in settlement in Maras, while the archival record offers the plausible explanation that the local population was removed from the area (Quave et al., 2018) and subsequently replaced through a transition toward lands and laborers for particular royal lineages. 
Most archival documents associate Maras with royal lands dedicated to the ayllus of Thupa Inka Yupanqui and Wayna Qhapaq. The section of Maras where the site of Cheqoq is located, as well as the site itself, are credibly connected to these Inka rulers, with Wayna Qhapaq's lineage being more frequently linked in the documentary record. The Yucay Valley estate attributed to Wayna Qhapaq included parts of Maras around Cheqoq and northward from Maras into what is now called the Sacred Valley (Covey and Amado, 2008; Segalini, 2017; Toledo, 1940[1571]; Villanueva, 1970). Among the ethnic groups making up the Yucay estate in 1571 were retainers (yanakuna) from Quichua, Qolla, Chanka, Xaquixaguana, Yauyo, and Cañari ethnic groups; these also included individuals born within the Yucay Valley before the Inka conquest (Covey and Amado, 2008: 294-6). Thus, there were yanakuna in the Maras region connected to Wayna Qhapaq's descent group and the parts of Maras attributed to that lineage likely included Cheqoq.

One of the Inka-period corporate kin groups or "ayllus" of the Maras Plain was called "Ayllu Checoc." It was reduced into the town of San Francisco de Maras in 1571 and at least 21 members of Ayllu Checoc were among the yanakuna inherited by Wayna Qhapaq's greatgranddaughter Beatriz Clara Coya as part of his royal estate; it was later subsumed into the Marquisate of Oropesa (Covey and Amado, 2008; Villanueva, 1970). Ayllu names in the Maras region and surrounding areas tend to be linked to toponyms, as found in surveys of late 16thcentury land tenure (Covey and Quave, 2017); it is reasonable to link the inheritance of the Checoc ayllu to the archaeological site of Cheqoq which is located on Cheqoq hill in a landscape of relatively stable toponyms. Additionally, in the 1595 repartition of lands to the ayllus of San Francisco de Maras, the border markers for Ayllu Checoc include storehouses made of quincha, which is the type of archaeological storehouse present at the Cheqoq site (ARC Urubamba 1594-1595. f.11v-12v). ${ }^{3}$ Combining both archaeological (Quave, 2012; Quave et al., 2013) and archival evidence (AGI Justicia 481, cited in Glave, 2017: 106; Toledo, 1940[1571]: 108), Ayllu Checoc was evidently a settlement of around 400 retainers that included specialists for quarrying, salt collection, and making pottery. Cheqoq and the retainer laborers resettled there were part of this larger Yucay Valley estate associated with Wayna Qhapaq's faction.

\section{Methods and material correlates}

Around 60 to 70 single-room structures existed at Yanawilka and all appeared to be domestic in function (Figure 2). The structures clustered on and around two low hills, each with a large rocky outcrop. The settlement structure likely reflected a moiety social structure (Hu, 2019). The interiors of four structures, two from each presumed moiety, were completely excavated $\left(71 \mathrm{~m}^{2}\right.$ in area with $25.93 \mathrm{~m}^{3}$ of sediment volume). All sediment was screened using a $1 / 4$ " screen, and $15 \mathrm{~L}$ of backfill was screened every two hours with a $1 / 8$ " geological sieve to ensure that no small artifacts were systematically missed. Flotation samples were taken in each context and yielded botanical, ceramic, and faunal remains.

\footnotetext{
${ }^{3}$ Thank you to R. Alan Covey and Donato Amado for sharing this transcription.
} 


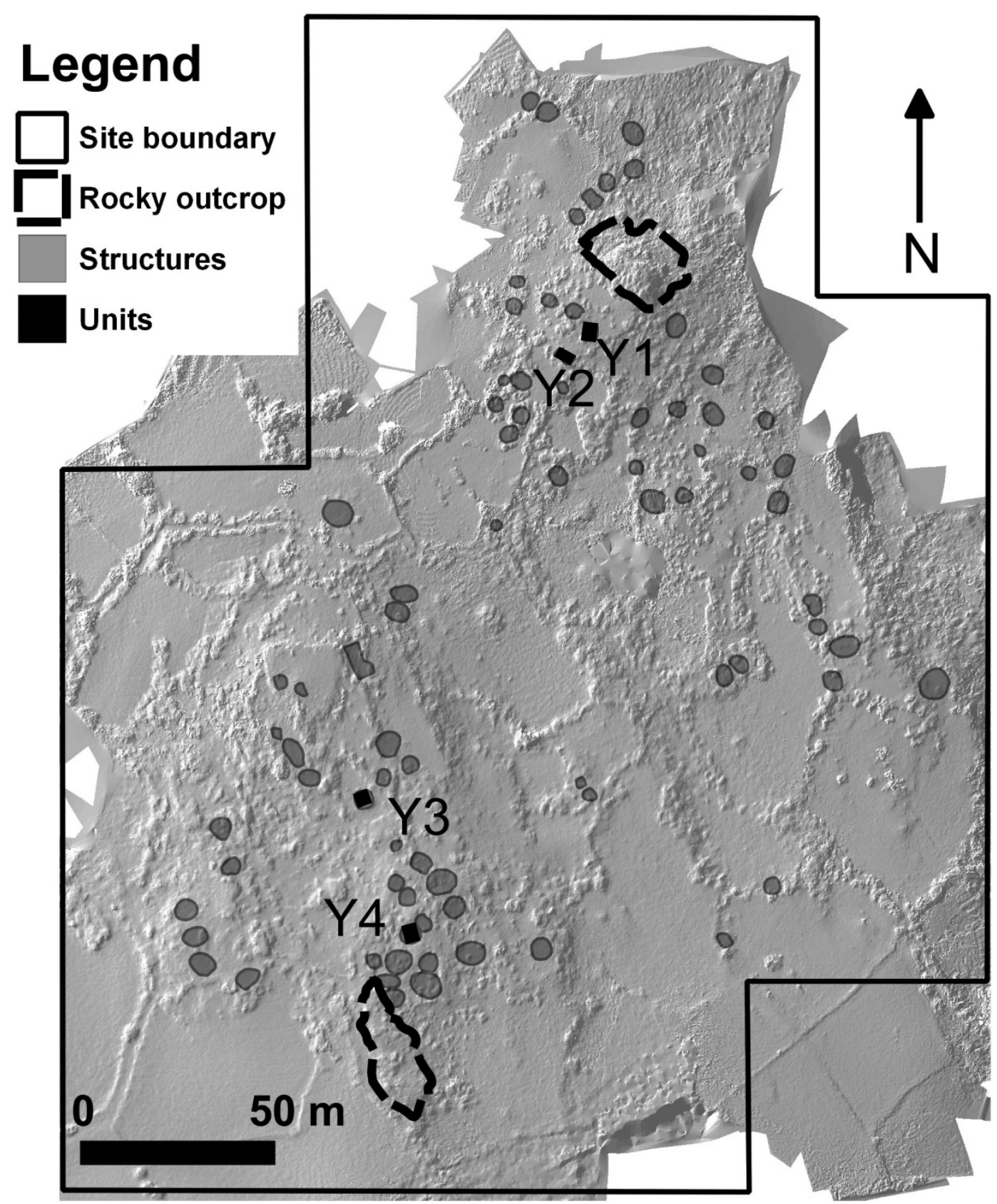

Figure 2: Map of Yanawilka with the excavation unit locations. Figure by Quave and Hu, 2020; available at http://dx.doi.org/10.17632/ftt9mcw2h.3 under a CC-BY4.0 license.

At Cheqoq, horizontal excavations were in domestic areas, storehouses (Covey et al., 2016), and a pottery workshop (Quave, 2017). The present analysis derives from the six intensively sampled domestic areas $\left(152 \mathrm{~m}^{2}\right.$, with $64.45 \mathrm{~m}^{3}$ of sediment volume; Areas $\mathrm{G}, \mathrm{H}, \mathrm{M}$, $\mathrm{N}$, and $\mathrm{R}$ ) within the 12-ha domestic sector of Cheqoq (Figure 3). We do not know how many total structures were in this area, due to overburden obscuring the majority of structures. Domestic terraces were stone-lined and of irregular, variable shape and size. Within each terrace, we excavated between $14 \mathrm{~m}^{2}$ and $41 \mathrm{~m}^{2}$ to take a sample of domestic life, including indoor and outdoor areas and the remains of walls, floors, and patios. This analysis also 
includes relevant results from the pottery production area excavated at Cheqoq $\left(33 \mathrm{~m}^{2}\right.$, with $33.95 \mathrm{~m}^{3}$ of sediment volume; Area $U$ ). All macroscopic artifact types were analyzed, including carbonized macrobotanicals (hand-recovered, dry screened, floated or wet screened) and animal bones. Flotation samples yielded heavy fraction remains of micro-artifacts, which were also collected and analyzed (Kennedy and Quave, 2019).

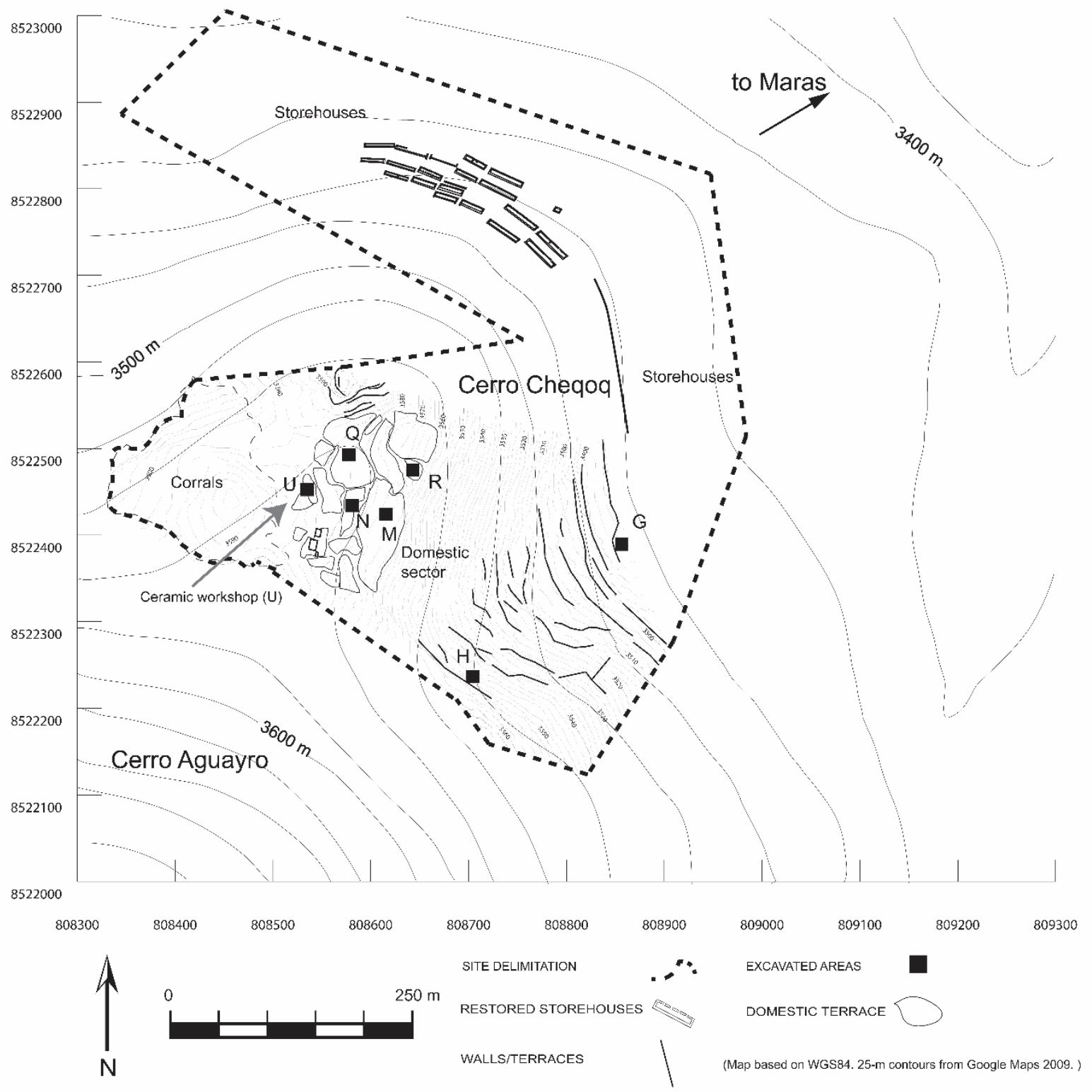

Figure 3: Map of Cheqoq with the excavation unit locations. Figure by Quave and Hu, 2020; available at http://dx.doi.org/10.17632/ftt9mcw2h.3 under a CC-BY4.0 license.

Laborer households at Yanawilka and Cheqoq are compared here to reconstruct the materiality of quality of life (wealth at the household level; hereafter "QOL"), prosperity (wealth at the community level), and prestige (capabilities and inter-community connections) with regard to 
expressions of multidimensional, intersectional identities. The material correlates for evaluating prosperity and prestige are based on a conceptual framework developed by Michael E. Smith (2019) that takes recent conversations in international policy and economics and applies them to archaeological data. These material correlates are also based on earlier work by Smith in which he proposed methods of measuring household wealth (1987), but this more recent framing differs in emphasizing that QOL includes not just economic wellbeing but also social and cultural connectedness and stability (2019; see also the concept of ontological security as espoused by Giddens [1991]).

Smith (2019) proposes measuring QOL and prosperity by examining the archaeological standard of living, diversity of possessions and external social networks, collective construction projects, residential stability, population growth, settlement longevity, and resilience to external shocks. In this study, from among Smith's proposed indices of QOL and prosperity, we are focused on household and community wealth and household capabilities (external social networks) (Table 1). We adapt Smith's material correlates and divide them into indicators of prosperity and prestige.

Table 1. Material correlates of prosperity/wealth and prestige used in this study that were adapted from the framework of Smith (2019).

\begin{tabular}{|l|l|l|}
\hline $\begin{array}{l}\text { Component } \\
\text { (Smith 2019) }\end{array}$ & $\begin{array}{l}\text { Index and material correlates } \\
\text { (Smith 2019) }\end{array}$ & $\begin{array}{l}\text { How included in this study (Hu } \\
\text { and Quave) }\end{array}$ \\
\hline $\begin{array}{l}\text { Quality of life: } \\
\text { household wealth } \\
\text { / Prosperity: } \\
\text { community wealth }\end{array}$ & $\begin{array}{l}\text { Standard of living - durable goods } \\
\text { within individual households and } \\
\text { within communities }\end{array}$ & $\begin{array}{l}\text { Prosperity/wealth: \% decorated } \\
\text { pottery, ceramic density, faunal } \\
\text { density, obsidian and other foreign } \\
\text { goods densities }\end{array}$ \\
\hline $\begin{array}{l}\text { Quality of life: } \\
\text { household } \\
\text { capabilities }\end{array}$ & $\begin{array}{l}\text { External social networks - 1) } \\
\text { presence of foreign goods; } 2) \\
\text { locally-made goods that share style } \\
\text { with larger regions }\end{array}$ & $\begin{array}{l}\text { Prestige: proportion of imperial } \\
\text { pottery style and form, charred } \\
\text { bone (as proxy for Inka commensal } \\
\text { practices) }\end{array}$ \\
\hline
\end{tabular}

To assess differences between resettled and normal tribute-paying communities, we will compare Yanawilka (resettled mitmaqkuna) and Cheqoq (resetted yanakuna) with the more autonomous provincial settlements of the Sausa (Upper Mantaro Valley; D'Altroy and Hastorf 2001) and Pulapuco (a Lucana ethnic community in Ayacucho; Abraham 2010). We hypothesize that prosperity was lower at Yanawilka and Cheqoq than in normal subject communities; that there were lower levels of durable goods than elsewhere and that resettled laborers were excluded from external social networks. The material correlates for wealth are the level of investment in architecture, and standard densities of ceramic, faunal, obsidian, and other foreign items. We also hypothesize that prestige measures may be uneven due to differential adoption of Inka practices that reflect how certain households and communities accepted and adopted Inka value systems. The material correlates for state-oriented prestige, as indicated by affinity toward Inka commensal practices, are the proportion of Inka-style 
pottery, ratio of unrestricted to restricted forms of pottery, and percentage of charred faunal remains (proxy for roasting). By comparing standard densities of artifacts using the volume of excavated sediment, we mitigate the effects of differences in occupation duration. Botanical remains did not factor into the analysis because of the extreme sensitivity of standard density of charred botanical remains to taphonomy and methods of recovery. For example, the soil conditions were very alkaline at Yanawilka, which promoted heavy fragmentation of charred botanical remains (Braadbaart et al., 2009).

\section{Comparing prosperity and prestige at Cheqoq and Yanawilka}

\section{Intrasite household wealth patterns}

The emphasis in this study is on overall QOL, but we will first explain the internal distinctions in prosperity at each site, via household wealth. Some material correlates of wealth commonly used in archaeological studies, such as the size of the domestic structure and species diversity of foodways, did not correspond with clear wealth differences at Cheqoq and Yanawilka (Hu, 2016; Quave, 2012; Quave et al., 2019). Intrasite differences in construction investment was not pronounced at both sites. Distinguishing consistent wealth differences at Cheqoq was more complicated than at Yanawilka, perhaps reflecting the multiethnic character of Cheqoq compared to the single ethnic group composition of Yanawilka.

At Cheqoq, where there were quantifiable differences in wealth, they did not overlap much across categories of durable goods wealth. For each durable goods category there were either no intrasite differences or one household had more than others in that particular category but not in many categories. Area $\mathrm{R}$ yielded high densities of bone and charred bone. Area $\mathrm{N}$ had higher densities of bones and of charred bone, as well as higher proportions of Cuzco-Inka pottery and serving vessels. In Area $Q$, there were also higher numbers of Inka pottery and serving vessels, as well as a rich offering cache described below. However, all households yielded metal and/or marine shell in small quantities. There was even access to camelid elements (considering high and low meat yield, following Sandefur [2001]) across households and even access to tender and tough camelid meat (as seen through animal age-at-death, following categories by Sandefur [2001]). There were minor differences in faunal diversity (all were primarily eating camelid and cuy [Cavia porcellus], with rare contributions of wild fauna).

At Yanawilka, one structure (Y1) stood out among the rest in terms of overall artifact richness: ceramic sherd density, faunal remains density, and diversity of obsidian sources used (see Table 3). It also had the highest occurrence of Inka (both Cuzco-Inka and provincial Inka) ceramic sherds (13 from Y1 versus 3 for all other structures) and decorated sherds (17 out of 45 in total). $Y 1$ also had the highest proportion of charred faunal remains $(49.5 \%$ by mass versus an average of $23.3 \%$ for all other structures). Structure $Y 1$ was only a few meters away from one of the two principal sacred rocky outcrops of the site, a possible reflection of its status and wealth. Despite its artifact richness, structure $\mathrm{Y} 1$ was not particularly large, with an interior space of only $16 \mathrm{~m} 2$, about average for the site. Future excavations at Yanawilka will clarify if there was a statistical correlation between artifact richness and size of the interior space of a structure. 
Hu \& Quave 2020

Household capabilities, community wealth, and affinity toward Inka commensal practices

\section{Architecture}

The masonry at the yanakuna site Cheqoq showed more investment overall than at the mitmaqkuna site Yanawilka. The stones were more regularly aligned and the walls were better defined at Cheqoq, yet stone courses were few (the rest of the structure appears to have been adobe) and there was a lack of standardized forms. At Yanawilka, the domestic structures had no more than two courses of poorly fitted stone, with the rest of the structure being presumably adobe or thatch. The masonry at the Sausa sites and in Pulapuco, normal subject communities in two Inka provinces, showed more investment than at both Cheqoq and Yanawilka. The Sausa sites and Pulapuco structures had many courses of stone and were often well-fitted with chinking stones.

Table 2. Comparison of prestige and prosperity/wealth measures at Yanawilka and Cheqoq.

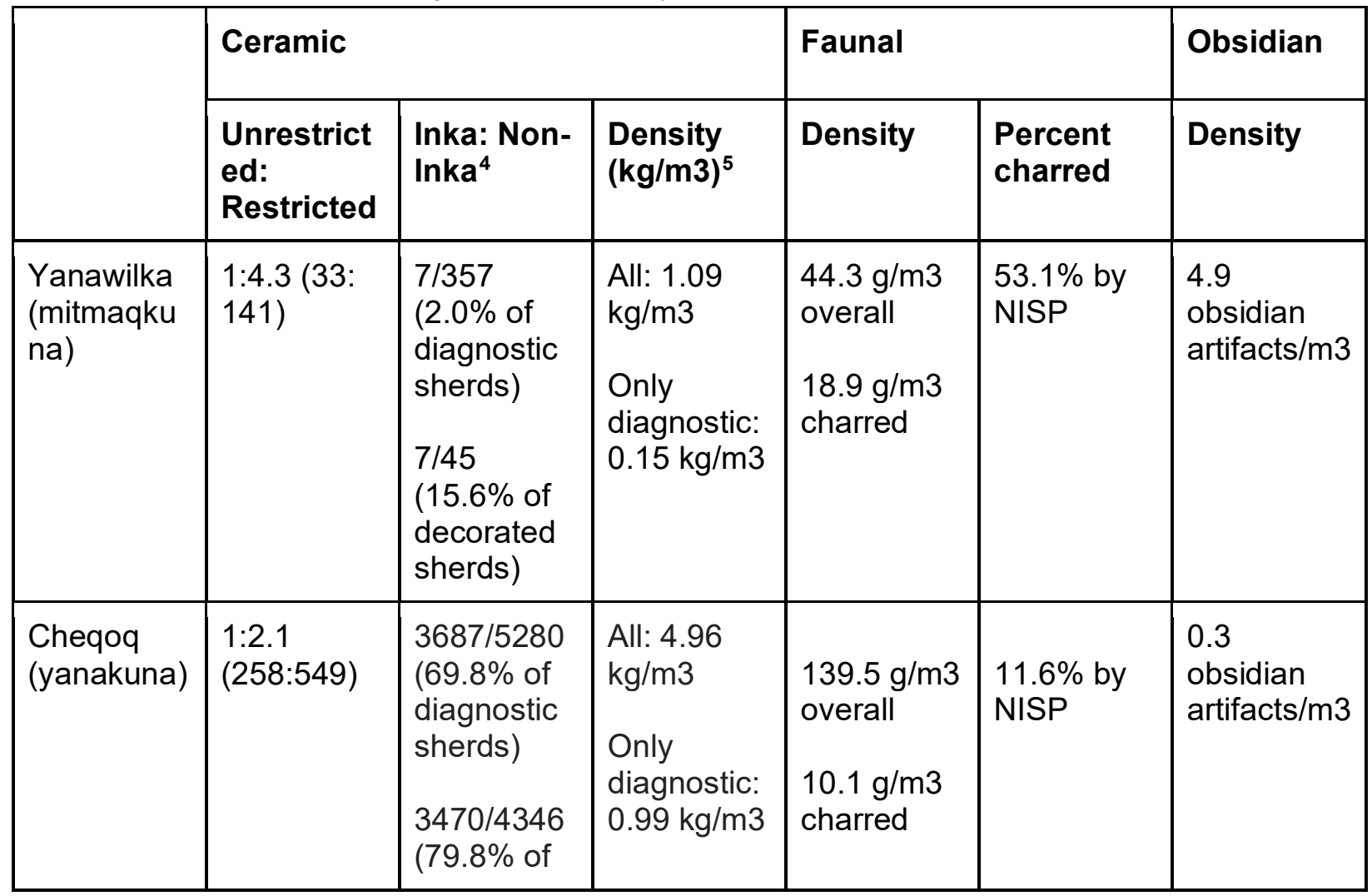

\footnotetext{
${ }^{4}$ Comparison of Cuzco-Inka sherds (identified by style and technology) to all recovered sherds. For Yanawilka, the denominator includes all recovered sherds. For Cheqoq, the denominator includes only "diagnostic" materials. "Diagnostic" pottery at Cheqoq included all recovered ceramics except undecorated body sherds of any size and any sherd smaller than a Peruvian nuevo sol coin.

${ }^{5}$ Including only diagnostic sherds at Cheqoq.
} 


\begin{tabular}{|l|l|l|l|l|l|l|}
\hline & $\begin{array}{l}\text { decorated } \\
\text { sherds) }\end{array}$ & & & & \\
\hline
\end{tabular}

\section{Ceramic form and style}

We compare wealth (the quantity and types of durable goods available to households) and external social networks (through the non-local goods available to households and the availability of regionally significant goods) through the forms and styles of pottery in resettled laborer households (Table 2). The comparison of unrestricted vessel forms (namely bowls and plates) to restricted forms (all else, including jars and pots for storage, serving, and cooking) provides an approximation of the engagement with Inka culinary practices, as explained by Bray (2003). We assess form with regard to all styles, including utilitarian vessels, as we are asking about the functional culinary and storage practices implied in these ratios. Bray previously found that there was a ratio of 1:4.6 open to closed vessels in Inka provinces (2003: 19), with a ratio of $1: 2.8$ in the Inka heartland. The ratios at Yanawilka and Cheqoq are close to meeting these ratios (1:4.3 at Yanawilka and 1:2.1 at Cheqoq) and point to a greater emphasis on individual serving vessels in the heartland at Cheqoq.

Ceramic styles are also compared to assess the level of consumption of Cuzco-Inka (imperial) style wares. Cuzco-Inka pottery is a standardized style and technology of pottery that is highly recognizable due to its consistency in forms, motifs, polished finishes, and clay and temper properties (Bray, 2000; Rowe, 1944:47-49; Valcárcel, 1934, 1935). Evaluating the proportions of decorated and specifically Cuzco-Inka decorated wares in these assemblages provides insight into access for mitmaqkuna and yanakuna. The use of the visible emblems of Inka authority and identity (Bray 2000, 2003; Morris, 1995) may indicate to us how much these populations were able to engage in imperial culture and in what ways that engagement was restricted, if at all.

Compared to Yanawilka, Cheqoq had a much higher occurrence of Cuzco-Inka style pottery and of decorated pottery overall. Cheqoq's representation of Cuzco-Inka style pottery was much higher than other heartland sites as well. For comparison, of all decorated sherds, just 18 percent at Pukara Pantillijlla was Cuzco-Inka style and just 23.6 percent at Ak'awillay was Cuzco-Inka (Quave and Covey, 2015: 120). A complicating factor is that Cheqoq was also a settlement where some yanakuna were specialist potters making Cuzco-Inka wares (Quave, 2017). The proportions of Inka pottery there are higher than other core sites and substantially higher than at Yanawilka, yet the Cheqoq laborers were restricted from use of imperial goods in significant ways. While acknowledging the problem of comparison due to on-site production at Cheqoq, we also find that the households at Cheqoq used only certain morphologies of CuzcoInka pottery from the on-site workshop (Quave, 2012: Table 7.3) and that there was a relatively high presence of Cuzco-Inka waster sherds (1.4\%) in the domestic assemblage; this latter statistic is high for wasters, which are not always visible (Stark, 1985: 174-177), and indicates that they were using castoffs from the workshop. In whatever manner these Cuzco-Inka wares made their way into Cheqoq households, it's notable that the residents of those households chose to use these highly visible emblems of imperial identity and authority. 
In contrast to Cheqoq, the inhabitants of Yanawilka did not engage in pottery production. There was no evidence of pottery production at the site such as waster sherds. The extremely low presence of Inka ceramics--only 32 sherds, of which seven were Cuzco-Inka--at Yanawilka indicated that the inhabitants of Yanawilka relied on local ceramic exchange networks that were not mediated directly by the Inka. The sherds at Yanawilka were overwhelmingly utilitarian, with less than $1 \%$ out of 5734 total sherds having any kind of decoration (more than one color, appliqué designs, incisions, etc.). The non-Inka decorated ceramic assemblage at Yanawilka most resembled the one at the Inka provincial settlement of Pulapuco, also located in the modern region of Ayacucho (Abraham, 2010). Pulapuco was inhabited by the Lucana ethnic group, who had settlements within a day or two's journey from Yanawilka (Quichua, 2013: 23). Given the fragmented ethnic composition of Inka Vilcashuamán province due to the mitmaq policy, it is highly likely that the inhabitants of Yanawilka engaged in ceramic exchange with different ethnic groups. The ceramics of Yanawilka did not resemble the ceramics of their presumed heartland in the Inka Condes province, but rather the local non-Inka ceramics (Lucana and Chanka).

The ceramic densities at Cheqoq and Yanawilka are relatively low compared to normal subject communities. For example, the Sausa settlements under Inka rule had much higher ceramic densities, with $13.52 \mathrm{~kg} / \mathrm{m} 3$ versus approximately $1 \mathrm{~kg} / \mathrm{m} 3(0.15 \mathrm{~kg} / \mathrm{m} 3$ diagnostics $)$ at Yanawilka and $5 \mathrm{~kg} / \mathrm{m} 3$ at Cheqoq (1 kg/m3 diagnostics). Even commoner households in Sausa communities had much higher ceramic densities than at Cheqoq and Yanawilka, with 11.64 kg/m3 (Costin, 1986: 280). Pulapuco, another normal subject community, had a higher density than Yanawilka, with $4.2 \mathrm{~kg} / \mathrm{m} 3$, but was close to the Cheqoq weight density. ${ }^{6}$ For being a ceramic production center, Cheqoq had a relatively low ceramic density and the low densities are one line of evidence that the labor communities of Cheqoq and Yanawilka were materially poor; at Cheqoq, the contrast of local ceramic production with the relatively low ceramic densities indicates that they were alienated from their labor.

\section{Foodstuffs}

Because botanical and faunal diversity did not clearly correlate with wealth differences within Cheqoq and Yanawilka, we focus on the standard densities of faunal remains, which have been reliable in differentiating status and wealth differences elsewhere in the Andes (e.g., Sandefur, 2001). At all sites, camelids dominated the faunal assemblages. Yanawilka had a lower overall faunal density $(44.3 \mathrm{~g} / \mathrm{m} 3)$ than Cheqoq $(139.5 \mathrm{~g} / \mathrm{m} 3)$. As with the ceramics, the faunal remains also point to Cheqoq and Yanawilka being poorer than the Sausa subject communities $(485.0 \mathrm{~g} / \mathrm{m} 3)$ and the Lucana subject community at Pulapuco $(157.6 \mathrm{~g} / \mathrm{m} 3)$. The

\footnotetext{
${ }^{6}$ A confounding factor for standardizing the weights and counts of all pottery at Cheqoq is that three of the six sampled households had Formative period occupations beneath Inka floors. For diagnostic weights and counts, Formative materials were removed, but they could not be fully removed from the nondiagnostic sherd counts and weights and thus contribute some "noise" to the density measures. For the domestic areas without Formative occupations beneath their floors the overall ceramic densities are $2.2 \mathrm{~kg} / \mathrm{m} 3$ and 312 sherds $/ \mathrm{m} 3$. Considering just the three single-occupation domestic areas, Cheqoq's ceramic wealth is well below that of regular subject communities.
} 
commoner Sausa households enjoyed more access to meat than the richest households at Yanawilka and Cheqoq (Table 3 and Table 4).

Charred bones are a good proxy for roasted meats (Hastorf, 2017; Jennings and Duke, 2018; Sandefur, 2001; Quave et al., 2019). Roasting was more fuel intensive than stewing or boiling and was thus reserved for special feasts (Sandefur, 2001: 194). As expected, the Sausa sites have the highest density of charred bones $(33.1 \mathrm{~g} / \mathrm{m} 3)$ compared to Cheqoq $(10.1 \mathrm{~g} / \mathrm{m} 3)$ and Yanawilka (18.9 $\mathrm{g} / \mathrm{m} 3)$. More unexpected is the relatively high density of charred bone at Yanawilka compared to the total density of bone, $18.9 \mathrm{~g} / \mathrm{m} 3$ charred versus $44.3 \mathrm{~g} / \mathrm{m} 3$ overall, representing $42.7 \%$ of the total mass. At the Sausa sites and at Cheqoq, charred bone comprised only a small fraction of the total assemblage, $6.8 \%$ and $7.2 \%$ by mass, respectively, indicating that most meat was probably stewed or boiled for daily consumption. We interpret that Yanawilka had the least access to meat overall and mainly consumed it during special occasions. The Inka provisioned meat to communities on special occasions (Hastorf, 2017; Knudson et al., 2012). In contrast to the Sausa sites and Cheqoq, it appears that the majority of the meat consumed at Yanawilka came from these occasional provisions. Because internal stratification at Yanawilka was particularly pronounced in regards to meat consumption (Table 3 ), the normal population at Yanawilka experienced severe restriction of meat in comparison to the Sausa sites.

Roasted meats were part of the "haute cuisine" of the Inka, and one would assume that the more roasted meats in relation to stewed meats consumed, the more cultural affinity toward the Inka there is (Jennings and Duke, 2018; Quave et al., 2019). Nevertheless, our analysis shows the importance of taking into account overall meat consumption. Yanawilka utilized Inka ceramics the least and yet had the highest proportion of charred faunal remains. The inhabitants of Yanawilka only rarely enjoyed the "good life" that the Inka promised to the mitmaqkuna as a group. The Sausa sites, in contrast, experienced a slight increase in meat consumption overall under Inka rule, even though elite consumption declined. The Spanish chronicler Cobo (1990[1653]:198) stated that commoners in the Inka empire ate very little meat and only during festivals and banquets. Our research, however, shows that this statement was not universally true, as there was extreme inequality between different communities. Normal subject communities like the Sausa may have had greater access to meat on average.

Table 3: Comparison of bone and charred bone densities at Sausa sites and Yanawilka. Sausa data calculated from Sandefur (2001: 199).

Bone density $\left(\mathrm{g} / \mathrm{m}^{3}\right) \quad$ Charred bone density $\left(\mathrm{g} / \mathrm{m}^{3}\right)$

$\begin{array}{lll}\text { Wanka III elite } & 675.8 & 49.04\end{array}$

Wanka III commoner

430.3

28.46 
Hu \& Quave 2020

Wanka overall

Y1

Average of $\mathrm{Y} 2, \mathrm{Y} 3$, and $\mathrm{Y} 4$

Yanawilka overall
485.0

137.4

15.1

3.49

18.9

Table 4: Comparison of bone and charred bone densities at Cheqoq

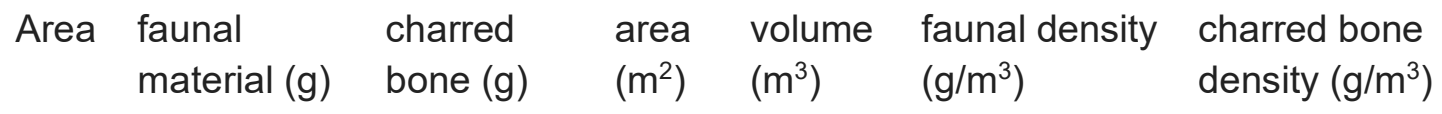

\begin{tabular}{lllllll}
\hline $\mathrm{G}$ & 30.6 & 0.00 & 16 & 5.888 & 5.20 & 0.00 \\
$\mathrm{H}$ & 3459.6 & 188.25 & 41 & 20.225 & 171.06 & 9.31 \\
$\mathrm{M}$ & 1828.2 & 110.60 & 23 & 10.114 & 180.76 & 10.94 \\
$\mathrm{~N}$ & 1806.7 & 209.40 & 17 & 5.794 & 311.82 & 36.14 \\
$\mathrm{Q}$ & 881.6 & 70.25 & 41 & 18.862 & 46.74 & 3.72 \\
$\mathrm{R}$ & 986.05 & 71.40 & 14 & 3.568 & 276.36 & 20.01
\end{tabular}

\section{Obsidian}

Because geological sources of obsidian were not local to Yanawilka and Cheqoq, the density of obsidian artifacts can indicate how much access the inhabitants had to external obsidian exchange networks. The Inka likely restricted the flow of obsidian to subject communities or did not increase the flow to communities that already had little obsidian (Earle, 2001; Hu and Shackley, 2018). Cheqoq and Yanawilka had very low densities of obsidian, and there was no evidence of obsidian tool production at Cheqoq given that only 5/17 of the obsidian artifacts were flakes or angular debris. In general, communities under Inka rule did not 
enjoy access to great quantities of obsidian, even when they were located close to major sources (Abraham, 2010; Earle, 2001; Hu and Shackley, 2018). In contrast to prestige goods that served to increase intra-community class distinctions, the free exchange of obsidian can pose a military threat through making weapons of war and bolstering inter-community economic cooperation across social classes. The restricted quantities of obsidian at settlements under Inka rule probably reflect the Inka strategy of minimizing direct inter-community economic exchange to prevent political alliances not amenable to Inka rule (Bray, 1992).

\section{Other foreign goods}

At Cheqoq, yanakuna were connected to external social networks through other material types, yet at Yanawilka prestige item exchange network connections were restricted to rarelyoccurring Inka pottery. Portable wealth goods such as metal, shell, and semiprecious stone play important roles in signalling wealth and status (Owen, 2001). Prospering through external connections in limited and specific ways, at Cheqoq we identified three types of foreign goods: metal, seashell, and semiprecious stone. Metal objects at Cheqoq were mostly fragments of personal adornment items or tools, including Area $\mathrm{H}$ with a needle, a scrap of bronze, and a clump of metal drippings; Area M with an unidentified nail-like object (cf. object 540 [Owen, 2001: 271]) and a piece of a possible tweezer (cf. object 551 [ibid.]); in Area $\mathrm{N}$ a broken tupu with rounded and pierced end (cf. object 581 [ibid.]); in Area Q three metal scraps; in Area R a nail-like copper object; as well as a small spoon in the pottery workshop. Across domestic contexts there were 15 marine shell fragments, with two more in the pottery workshop. Among semi-precious stones, there was a single chrysocolla bead in Area R and a worked schist pendant in the pottery workshop of Area U.

\section{Comparing resettled and non-resettled communities}

The resettled communities of Cheqoq (yanakuna) and Yanawilka (mitmaqkuna) had lower wealth and prosperity than the non-resettled communities of the Sausa and Pulapuco. Prestige, as measured by indicators of affinity toward Inka commensal practices, did not covary with wealth and prosperity (Table 5 , Figure 4). Cheqoq, being a community of yanakuna retainers who probably had the most daily interaction with the Inka nobility, unsurprisingly had the highest indices of prestige overall. The agricultural mitmaqkuna of Yanawilka, who probably had little face-to-face interaction with the Inka nobility, had lower indices of prestige than the yanakuna of Cheqoq and the Sausa communities. Botanical, bioarchaeological, and ceramic lines of evidence indicate that Inka-sponsored feasting was an important part of life in the Sausa communities, which is consistent with their relatively high indices of prestige (Costin and Earle, 1989; D'Altroy and Hastorf, 2001; Hastorf, 1993; Hastorf and Johannessen, 1993). The Lucana community of Pulapuco had the lowest indices of prestige, which is consistent with other lines of evidence that the community was relatively autonomous and not directly ruled (Abraham, 2010).

The archaeological evidence contradicts ethnohistorical accounts in two important ways. First, supposedly prestigious classes of people, such as the mitmaqkuna and yanakuna, may not have always enjoyed more material manifestations of prestige than normal subject 
Hu \& Quave 2020

communities. Second, the material benefits conferred to the mitmaqkuna and yanakuna may not have translated into overall community-level prosperity.

Table 5. Indicators of prestige and wealth/prosperity in resettled communities and non-resettled communities.

\begin{tabular}{|c|c|c|c|c|c|}
\hline & \multirow[t]{2}{*}{ Material correlate } & \multicolumn{2}{|c|}{ Resettled communities } & \multicolumn{2}{|c|}{ Non-resettled communities } \\
\hline & & $\begin{array}{l}\text { Cheqoq } \\
\text { (yanakuna) }\end{array}$ & $\begin{array}{l}\text { Yanawilka } \\
\text { (mitmaqkuna) }\end{array}$ & Sausa & Pulapuco \\
\hline \multirow{3}{*}{$\begin{array}{l}P \\
R \\
E \\
S \\
T \\
I \\
G \\
E\end{array}$} & $\begin{array}{l}\% \text { of decorated sherds } \\
\text { Inka (Prov. + Cuzco) }\end{array}$ & $84.7 \%$ & $35.6 \%$ & $47.7 \%$ & $4.6 \%$ \\
\hline & $\begin{array}{l}\text { Vessel form ratio } \\
\text { (unrestricted:restricted) }\end{array}$ & $1: 2.1(32 \%)$ & 1:4.3 (19\%) & 1:2.6 (28\%) & $1: 2.9(26 \%)$ \\
\hline & $\%$ Charred mass & $\begin{array}{l}7.2 \% \\
(10.1 \mathrm{~g} / \mathrm{m} 3)\end{array}$ & $\begin{array}{l}42.7 \% \\
(18.9 \mathrm{~g} / \mathrm{m} 3)\end{array}$ & $\begin{array}{l}6.8 \% \\
(33.1 \mathrm{~g} / \mathrm{m} 3)\end{array}$ & N/A \\
\hline \multicolumn{2}{|c|}{ Prestige (averaged ranking) } & 3.7 & 2.3 & 2.7 & (1.5) \\
\hline \multirow{6}{*}{$\begin{array}{c}\text { W } \\
\mathrm{E} \\
\mathrm{A} \\
\mathrm{L} \\
\mathrm{T} \\
\mathrm{H}\end{array}$} & \% Decorated ceramics & $7.5 \%$ & $0.8 \%$ & $20.4 \%$ & $7.7 \%$ \\
\hline & Density ceramics & $4.96 \mathrm{~kg} / \mathrm{m} 3$ & $1.09 \mathrm{~kg} / \mathrm{m} 3$ & $13.52 \mathrm{~kg} / \mathrm{m} 3$ & $4.19 \mathrm{~kg} / \mathrm{m} 3$ \\
\hline & Density faunal & $139.5 \mathrm{~g} / \mathrm{m} 3$ & $44.3 \mathrm{~g} / \mathrm{m} 3$ & $485.0 \mathrm{~g} / \mathrm{m} 3$ & $157.1 \mathrm{~g} / \mathrm{m} 3$ \\
\hline & $\begin{array}{l}\text { Density obsidian } \\
\text { (artifacts/m3) }\end{array}$ & 0.3 & 4.9 & 0.1 & 3.6 \\
\hline & $\begin{array}{l}\text { Density other foreign } \\
\text { goods (artifacts/m3) }\end{array}$ & 0.4 & 0 & 1.7 & 0.2 \\
\hline & Architectural investment & $\begin{array}{l}\text { Third most } \\
\text { investment }\end{array}$ & $\begin{array}{l}\text { Least } \\
\text { investment }\end{array}$ & $\begin{array}{l}\text { Most } \\
\text { investment }\end{array}$ & $\begin{array}{l}\text { Second most } \\
\text { investment }\end{array}$ \\
\hline \multicolumn{2}{|c|}{ Wealth (averaged ranking) } & 2.3 & 1.5 & 3.5 & 2.7 \\
\hline
\end{tabular}




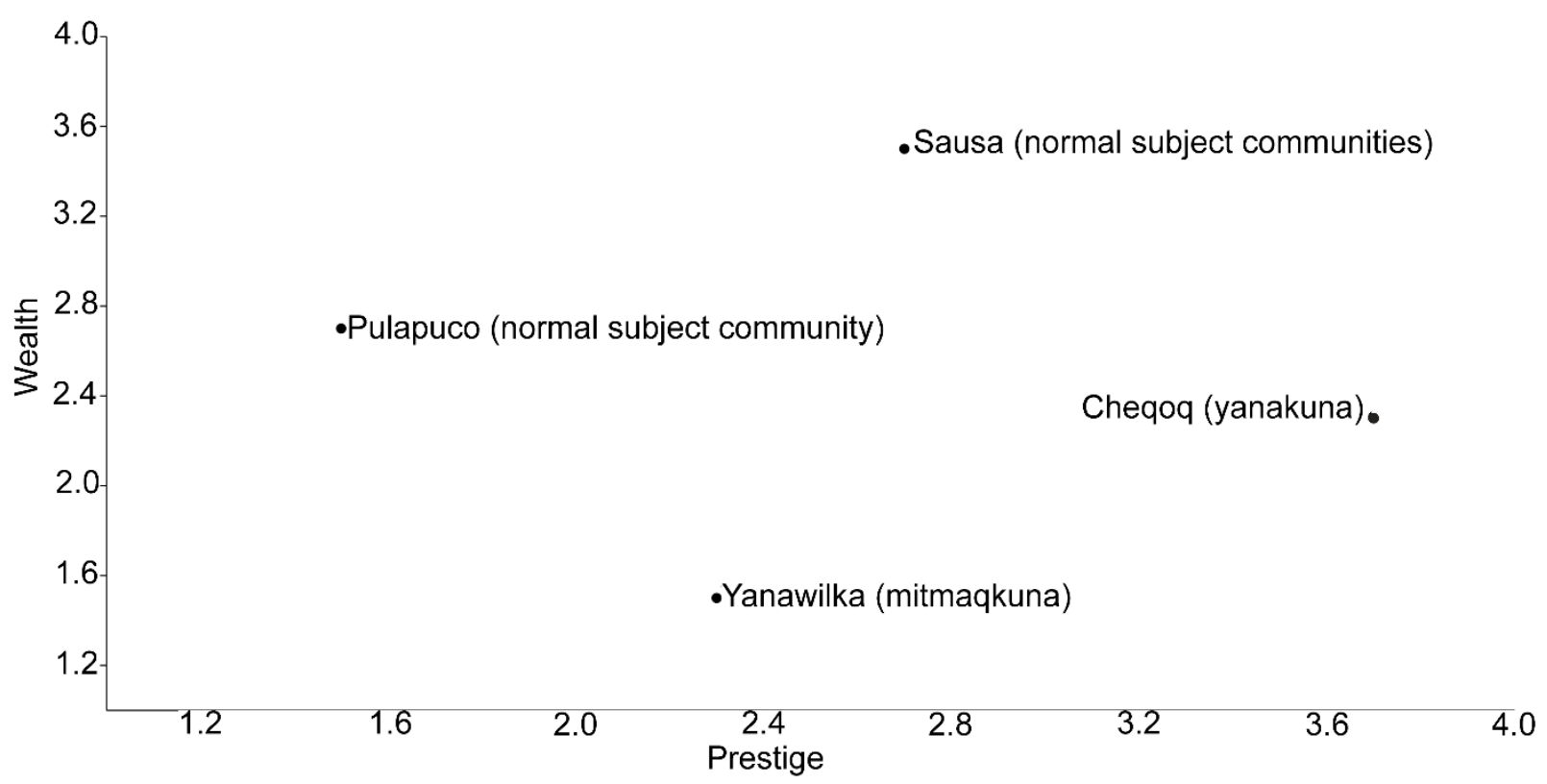

Figure 4. Bivariate plot of rankings of wealth and prestige indicators for the four sites compared in this study. Figure by Quave and Hu, 2020; available at http://dx.doi.org/10.17632/fttj9mcw2h.3 under a CC-BY4.0 license.

\section{Discussion}

What does it mean to enjoy an elevated social status yet be economically marginalized? Comparison of these two resettled laborer settlements with each other and with other settlements demonstrates that mitmaqkuna and yanakuna became enmeshed in the dominant material culture by their own volition but also through an uneven flow of gifts from noble and state overseers. They assimilated within the limitations they were assigned due to their subordinate positions in imperial society, but they also aspired to take on Inka attributes. Insofar as they were permitted access to the trappings of Inka life, it was incomplete and manifested differently at Yanawilka and Cheqoq.

The differences in household wealth may be due to different strategies of state consolidation among existing native communities versus Inka-created labor communities. For existing native communities, as in the case of the Sausa, the Inka took over much of the traditional host roles of the elites in regards to gifting and feasting. Thus, with the traditional elites losing the significant political power that comes from playing hosts, differences between the elites and commoners began to even out (Costin and Earle, 1989; Sandefur, 2001). In contrast, Inka-created labor communities, particularly those doing low-status agricultural work, were structurally dependent on the Inka for land, food, and security, so the Inka did not need to invest as much in the generous host role. Furthermore, exclusion of resettled communities from directly accessing external social and economic networks resembles strategies employed by the Inkas elsewhere. Bray, for example, found that in the Ecuadorian highlands the Inkas eliminated "horizontal linkages that could potentially lead to dangerous anti-Inka alliances. It could also be interpreted as a strategy for transforming regional interdependency into local dependency on 
the state" (1992: 230). Yanawilka was a poor community. Even the richest assemblage at Yanawilka (Y1) still did not compare to non-labor communities, as there were no luxury goods such as spondylus shell and metal. Although not as poor as Yanawilka, at Cheqoq, access to metal and shell was uncommon, and obsidian was rare.

The notion of privileges and material benefits being connected to the yana and mitmaq status is a pervasive assumption; where there has been much attention paid to the exploitation of the Colonial-era mita in comparison with the reciprocally generous institution of Inka-era labor tribute arrangements, yana and mitmaq service have been treated as neutral or beneficial. Our research reveals a more complex picture of people who were forcibly removed from their homelands, and, for the yanakuna, inserted into a pluralistic social reality and expected to be permanently connected to a new, royal household. Different classes of people experience colonial situations in different ways, with high levels of inequality between different types of communities, whether normal subject communities or state-sponsored labor communities. We show that even within the categories of resettled populations, such as the mitmaqkuna and yanakuna, access to wealth and privilege could diverge dramatically. Similarly, while the Sausa commoners as a whole may have enjoyed greater household wealth under the Inka, women bore the brunt of increased labor in food production (Hastorf, 1991, 1993, 2001).

John Rowe argued that although mitmaq and yana resettlement were not designed intentionally to culturally unify the empire but to extract labor and remove people from provincial loyalties, they nevertheless resulted in a more culturally unified and Inkanized subject population (1982: 94). With these currently available archaeological case studies, we demonstrate that neither cultural unification nor Inkanization was universal or uniformly practiced. As attached specialists and retainers, the yanakuna were essentially part of the royal Inka households, unlike the mitmaqkuna who lived in their own settlements and may not have had daily interaction with Inka domestic life. The Inka kept the yanakuna close, giving them access to some of what it is to be a noble Inka, but not allowing them to fully participate in Inka identity and autonomously accumulate wealth. Because both Cheqoq and Yanawilka were geographically close to Inka administrative capitals (Cuzco and Vilcas Huamán), the apparent higher levels of aspirational commensal behavior at yanakuna Cheqoq is not due to being geographically closer to Inka centers of power. The difference is probably due to the more intimate daily interactions the yanakuna had with the Inka. Archaeologists ought not to assume that the amount of Inka material culture correlates with the degree of Inka power over a group. The mitmaqkuna at Yanawilka and subjects at Sausa and Pulapuco had very little Inka material culture despite being in areas of high Inka control.

Rather than assimilating or acculturating, unfree laborers sought to be like the Inka on their own terms and in piecemeal fashion, even while they were not permitted to fully participate. The mitmaqkuna and yanakuna, at least at Yanawilka and Cheqoq, did not enjoy access to the fruits of the Inka Empire in two ways: they were relatively restricted from interregional trade networks and could not accumulate much community wealth. While restriction and control of interregional trade by the Inka has been well documented in archaeological and historical evidence (e.g., Bray, 1992; Hu and Shackley, 2018; Murra, 1962; Quave et al., 2018; Yacobaccio et al., 2002; Yacobaccio et al., 2004), the restriction of community wealth has not been documented archaeologically or historically for mitmaqkuna and yanakuna communities 
until this study. Unfree laborers strove for success under the Inka through adopting Inka table customs and commensal practices (Cheqoq).

The development of competing Inka lineages, with their attendant mosaics of improved lands, resettled peoples, and patchy, high-value resources (e.g., salt fields and quarries) led to a political landscape marked by factionalism among elites that introduced fragility into the lower classes of society as well. Such fragility of political institutions has recently been discussed by Dillehay and Wernke (2019) as an area deserving of further research; they argue that rather than seeing the state as a functionalist product delivered as promised, we ought to acknowledge that state institutions are weakened through the very strategies they use to mediate political order (2019: 20-21). In other words, elite strategies for making order may actually harm the lower classes of society, which is detrimental to the cohesion of the state altogether. The relative "success" of Inka factionalism may have accelerated the rate of wealth accumulation for the ruling elite, but it came at the expense of those laboring for them and formed weak bonds to the state in the process. In this study, we assessed the constructionist process of becoming Inka as a multidirectional formation that entails a contradiction of aspiring to Inka culture while having restricted access to the materials of everyday wellbeing. Inka state expansion and the expansion of unfree labor went hand-in-hand (D'Altroy, 2005). The Inka may have created the mitmaqkuna and yanakuna categories, but without the mitmaqkuna and yanakuna, the Inka would not have been able to fuel the dynamic factionalism that characterized their evolution.

\section{VIII: Conclusions and recommendations}

Creating aspirational Inkas out of the most marginalized is not unique to the Andean empire but is rather a phenomenon observed in multiple imperial and colonial cases, even today. Many states and empires forcibly resettle peoples by direct actions and through indirect economic policies that may coerce populations into transnational resettlement. People who must resettle are expected to take on dominant cultural elements and are convinced to buy into the values and practices of those who have placed them in unfair labor situations. Yet archaeological studies focused on consumption practices and assimilation have sometimes overlooked household and community hardships as part of the process of acculturating. Without economic freedom and robust external social connections, community prosperity is low, even if individual households possess relative wealth in variety and quantity of possessions.

This study offers some lessons for future research on the political economy of unfree labor. While the early Colonial accounts offer some details on the movement of people and the improvement of lands upon which they labored under Inka imperialism, there is little documentation of the treatment of those people. We showed how archaeological investigation can help understand how the Inkas masked exploitation under a veneer of generosity and how that exploitation resulted in a variety of types of exclusions from imperial society. Following D'Altroy and Hastorf (2001) and Smith (2019), we advocate for the comparative study of community wealth to understand the various kinds of social inequality that proliferate in imperial situations. At minimum, the standard densities of major artifact and ecofact categories are important to report for comparative research. Our study is limited by the dearth of published standard densities of artifacts elsewhere in the Andes. Many more domestic non-Inka settlements' archaeological assemblages need to be analyzed and published to support or 
refute the arguments in our preliminary study. Such comparative research is critical to providing alternatives to popular pro-colonialism narratives (e.g., Ferguson, 2005, 2012; Gilley, 2018) that emphasize the supposed net positive material benefits to the colonized. Archaeological methods may be the best hope for staking out a more confident position on the shape and intensity of structural violence. And these analyses must be undertaken from a perspective that accounts for multiple, intersecting systems of oppression.

\section{Acknowledgments}

We would like to thank Katherine Moore for consultations on quantifying faunal remains and are grateful to Sarah Abraham for providing unpublished data for contextualizing Pulapuco patterns. Yanawilka excavations were permitted by the Ministry of Culture-Peru (Resolución Directoral No 085-DGPC-VMPCIC/MC). Cheqoq excavations were permitted by the Instituto Nacional de Cultura-Cusco (Resolución Nacional 1579/INC, 2010). The first author thanks Lic. Alicia Miranda A. and the communities of Pomacocha, Vischongo, and Vilcas Huamán for assistance in excavations and the students of UNSCH for assistance in laboratory analysis. The first author also thanks Teresa Rosales T. and Víctor Vásquez S. for faunal analysis assistance and Anna Harkey with Sausa ceramic data assistance. The corresponding author thanks Lic. René Pilco V., Lic. Stephanie Pierce T., the Lucana-Morales family, and the community of Maras Ayllu for excavation assistance and appreciates Sarah Kennedy for the faunal analysis assistance. We thank the anonymous reviewers for their insightful feedback that improved this study, as well as the editors of the journal.

Funding: The first author received funding from the Institute of International Studies-UC Berkeley (John L. Simpson Memorial Research Fellowship), the Fulbright-Hays Doctoral Dissertation Research Abroad Fellowship, the Wenner-Gren Foundation (Dissertation Fieldwork Grant \#8265), the Archaeological Research Facility-Berkeley (Stahl Fund), and the Ford Foundation (Dissertation Fellowship). The corresponding author received funding from the National Science Foundation (Dissertation Improvement Grant BCS-938453), the National Geographic Society Committee for Research and Exploration (Young Explorers Grant 8691-09), the Fulbright Institute for International Education, and Southern Methodist University.

\section{Bibliography}

Research data

Quave, K.E., Hu, D., 2020. Resettled laborers in the Inka empire: A comparative study. Mendeley Data, V3, doi: 10.17632/ftt9mcw2h.3

\section{Unpublished archival source}

AGI (Archivo General de Indias). Justicia 481. Lima 21 de junio de 1591. Petición del protector Antonio de Heredia a nombre de los indios de Checo. 
Hu \& Quave 2020

ARC (Archivo Regional del Cusco). Archivo Histórico de la Notaria de Urubamba, Legajo 1 [1594-1595]. Repartición de tierras Valle de Urubamba CharcaguayllaPichingoto y San Francisco de Maras, año 1595.

\section{Published sources}

Abraham, S.J., 2010. Provincial Life in the Inca Empire: Continuity and Change at Pulapuco, Peru. University of California, Santa Barbara.

Alcina Franch, J., 1970. Excavaciones en Chinchero (Cuzco): Temporadas 1968 y 1969. Revista Española de Antropología Americana 5, 99-121.

Armengol, J.M., 2017. Slavery in black and white: the racialisation of (male) slavery in Frederick Douglass's Narrative and/vs. Toni Morrison's A Mercy. Postcolonial Studies 20, 479-493.

Battle-Baptiste, W., 2011. Black Feminist Archaeology. Left Coast Press, Walnut Creek.

Bauer, B.S., 2004. Ancient Cuzco: Heartland of the Inca. University of Texas, Austin.

Bauer, B.S., Stanish, C., 1990. Killke and Killke-related pottery from Cuzco, Peru, in the Field Museum of Natural History, Fieldiana, new ser., no. 15. Field Museum of Natural History, Chicago, III.

Betanzos, J. de, 2015. Juan de Betanzos y el Tahuantinsuyo: nueva edición de la Suma y narración de los Incas, Primera edición. ed. Fondo Editorial, Pontificia Universidad Católica del Perú, Lima, Perú.

Braadbaart, F., Poole, I., van Brussel, A.A., 2009. Preservation potential of charcoal in alkaline environments: an experimental approach and implications for the archaeological record. Journal of Archaeological Science 36, 1672-1679. https://doi.org/10.1016/j.jas.2009.03.006

Bray, T.L., 2003. Inka Pottery as Culinary Equipment: Food, Feasting, and Gender in Imperial State Design. Latin American Antiquity 14, 3-28.

Bray, T.L., 2000. Inca Iconography: The Art of Empire in the Andes. RES: Anthropology and Aesthetics 38, 168-178.

Bray, T.L., 1992. Archaeological survey in northern highland Ecuador: Inca imperialism and the País Caranqui. World Archaeology 24, 218-233. https://doi.org/10.1080/00438243.1992.9980204

Carabajal, P. de, 1965. Descripción Fecha de la Provincia de Vilcas Guaman Por el Illustre Señor Don Pedro de Carabajal, Corregidor y Justicia Mayor Della, Ante Xpristobal de Gamboa, Escribano de su Juzgado, en el Año de 1586, in: Jiménez de la Espada, M., Martínez Carreras, J.U. (Eds.), Relaciones Geográficas de Indias, Biblioteca de Autores Españoles. Real Academia Española, Madrid, pp. 205-219. 
Hu \& Quave 2020

Cieza de León, P. de, 1959. The Incas, The Civilization of the American Indian series, v. 53. University of Oklahoma Press, Norman.

Cieza de León, P. de, 1883. The Second Part of the Chronicle of Peru. Hakluyt Society, London.

Cobo, B., 1990. Inca religion and customs. University of Texas Press, Austin.

Cobo, B., 1979. History of the Inca Empire: an account of the Indians' customs and their origin, together with a treatise on Inca legends, history, and social institutions, The Texas Pan American series. University of Texas Press, Austin.

Cooper, B., 2016. Intersectionality, in: Disch, L., Hawkesworth, M. (Eds.), The Oxford Handbook of Feminist Theory. Oxford University Press, New York, pp. 385-406.

Costin, C.L., 2018. Crafting identity and wealth on the north coast of Peru, in: Bentz, M., Helms, T. (Eds.), Craft Production Systems in a Cross-Cultural Perspective. Habelt-Verlag, Bonn, Germany, pp. 171-183.

Costin, C.L., 1986. From Chiefdom to Empire State: Ceramic Economy among the Prehistoric Wanka of Highland Peru (Doctoral Dissertation). University of California, Los Angeles, Los Angeles.

Costin, C.L., Earle, T.K., 1989. Status Distinction and Legitimation of Power as Reflected in Changing Patterns of Consumption in Late Prehispanic Peru. American Antiquity 54, 691714.

Costin, C.L., Hagstrum, M., 1995. Standardization, labor investment, skill, and the organization of ceramic production in Late Prehispanic highland Peru. American Antiquity 60, 619-639.

Covey, R.A., 2014a. Local Populations, Royal Lineages, and State Entities in the Inca Occupation of the Xaquixaguana Plain, in: Covey, R.A. (Ed.), Regional Archaeology in the Inca Heartland: The Hanan Cuzco Surveys. University of Michigan Museum of Anthropology, Ann Arbor, pp. 153-174.

Covey, R.A., 2014b. Regional Archaeology in the Inca Heartland: The Hanan Cuzco Surveys, Studies in Latin American Ethnohistory \& Archaeology. University of Michigan Museum of Anthropology, Ann Arbor.

Covey, R.A., 2011. Landscapes and Languages of Power in the Inca Imperial Heartland (Cuzco, Peru). The SAA Archaeological Record 11, 29-32.

Covey, R.A., 2006a. Chronology, Succession, and Sovereignty: The Politics of Inka Historiography and Its Modern Interpretation. Comparative Studies in Society and History 48, 169-199.

Covey, R.A., 2006b. How the Incas built their heartland: state formation and the innovation of imperial strategies in the Sacred Valley, Peru, History, languages, and cultures of the Spanish and Portuguese worlds. University of Michigan Press, Ann Arbor. 
Covey, R.A., Amado González, D., 2008. The Marquisate of Oropesa and the Preservation, Collection, and Study of Its Documents, in: Covey, R.A., Amado González, D. (Eds.), Imperial Transformations in Sixteenth-Century Yucay, Peru. Museum of Anthropology, University of Michigan, Ann Arbor, pp. 30-34.

Covey, R.A., Aráoz Silva, M., Bauer, B.S., 2008. Settlement Patterns in the Yucay Valley and Neighboring Areas, in: Covey, R.A., Amado González, D. (Eds.), Imperial Transformations in Sixteenth-Century Yucay, Peru. Museum of Anthropology, University of Michigan, Ann Arbor, pp. 3-17.

Covey, R.A., Quave, K.E., 2017. The Economic Transformation of the Inca Heartland (Cuzco, Peru) in the Late Sixteenth Century. Comparative Studies in Society and History 59, 277309. https://doi.org/Doi: 10.1017/s0010417517000056

Covey, R.A., Quave, K.E., Covey, C.E., 2016. Inca Storage Systems in the Imperial Heartland (Cuzco, Peru): Risk Management, Economic Growth, and Political Economy, in: Manzanilla, L.R., Rothman, M.S. (Eds.), Storage in Ancient Complex Societies: Administration, Organization, and Control. Routledge, New York, pp. 167-188.

Crenshaw, K., 1991. Mapping the Margins: Intersectionality, Identity Politics, and Violence against Women of Color. Stanford Law Review 43, 1241-1299. https://doi.org/10.2307/1229039

Crenshaw, K., 1989. Demarginalizing the Intersection of Race and Sex: A Black Feminist Critique of Antidiscrimination Doctrine, Feminist Theory and Antiracist Politics. University of Chicago Legal Forum 1989, 139-167.

Croucher, S.K., 2015. Capitalism and Cloves: An Archaeology of Plantation Life on NineteenthCentury Zanzibar. Springer-Verlag, New York.

D'Altroy, T.N., 2005. Remaking the Social Landscape: Colonization in the Inka Empire, in: Stein, G.J. (Ed.), The Archaeology of Colonial Encounters. School of American Research Press, Santa Fe, pp. 263-295.

D'Altroy, T.N., 2001. Politics, resources, and blood in the Inka empire, in: Alcock, S.E., D'Altroy, T.N., Morrison, K.D., Sinopoli, C.M. (Eds.), Empires: Archaeological and Historical Perspectives. Cambridge University Press, New York, pp. 201-226.

D’Altroy, T.N., 1992. Provincial Power in the Inka Empire. Smithsonian Institution, Washington, D.C.

D’Altroy, T.N., Hastorf, C.A., 2001. Empire and Domestic Economy. Kluwer Academic/Plenum, New York.

Dillehay, T.D., Wernke, S.A., 2019. Fragility of Vulnerable Social Institutions in Andean States, in: Yoffee, N. (Ed.), The Evolution of Fragility: Setting the Terms. McDonald Institute for Archaeological Research, University of Cambridge, Cambridge, UK, pp. 9-24.

Douglass, F., 2018. The speeches of Frederick Douglass : a critical edition. Yale University Press, New Haven. 
Hu \& Quave 2020

Douglass, F., 2014. Narrative of the life of Frederick Douglass, an American slave, Penguin classics. Penguin Classics, New York.

Du Bois, W.E.B., 1972. The emerging thought of W. E. B. Du Bois: essays and editorials from the Crisis. Simon and Schuster.

Du Bois, W.E.B., 1935. Black Reconstruction in America: Toward a History of the Part Which Black Folk Played in the Attempt to Reconstruct Democracy in America, 1860-1880. Harcourt, Brace and Company, New York.

Earle, T., 2001. Exchange and Social Stratification in the Andes The Xauxa Case, in: D'Altroy, T.N., D'Altroy, T.N. (Eds.), Empire and Domestic Economy. Kluwer Academic/Plenum, New York, pp. 297-314.

Espinoza Soriano, W., 1983. Los mitmas plateros de Ishma en el país de los Ayarmaca, siglos XV-XIX. Boletín de Lima 30, 38-52.

Espinoza Soriano, W., 1973. Colonias de mitmas multiples en Abancay, siglos XV y XVI: Una información inédita de 1575 para la etnohistoria andina. Revista del Museo Nacional XXXIX, 225-299.

Espinoza Soriano, W., 1970. Los mitmas yungas de Collique en Cajamarca, siglos XV, XVI y XVII. Revista del Museo Nacional XXXVI, 9-57.

Falcón, F., 1918. Representación hecha por el licenciado Falcón en concilio provincial, sobre los daños y molestias que se hacen a los indios, in: Urteaga, H., Romero, C. (Eds.), Colección de Libros y Documentos Referentes a La Historia Del Perú. Sanmartí, Lima, pp. 134-176.

Farrington, I.S., 1995. The Mummy, Palace, and Estate of Inka Huayna Capac at Quispeguanca. Tawantinsuyu 1, 55-65.

Ferguson, N., 2012. Empire: How Britain Made the Modern World. Penguin UK.

Ferguson, N., 2005. Colossus: The Rise and Fall of the American Empire. Penguin.

Franklin, M., 2001. A Black feminist-inspired archaeology? Journal of Social Archaeology 1, 108-125. https://doi.org/10.1177/146960530100100108

Garcilaso de la Vega, E.I., 1989. Royal commentaries of the Incas, and general history of Peru. University of Texas Press, Austin.

Garnsey, P., Woolf, G., 1989. Patronage of the rural poor in the Roman world, in: WallaceHadrill, A. (Ed.), Patronage in Ancient Society, Leicester-Nottingham Studes in Ancient Society. Routledge, New York, pp. 153-170.

Giddens, Anthony., 1991. Modernity and self-identity: self and society in the late modern age. Stanford University Press, Stanford, Calif.

Gilley, B., 2018. The Case for Colonialism. Acad. Quest. 31, 167-185. https://doi.org/10.1007/s12129-018-9696-2 
Hu \& Quave 2020

Glave, L.M., 2017. Pedro Ortiz de Orué: el encomendero y la encomienda de Maras. Revista Andina 55, 95-124.

Gramsci, A., 1992. Prison notebooks, European perspectives. Columbia University Press, New York.

Gyarmati, J., Condarco, C., 2018. Inca Imperial Strategies and Installations in Central Bolivia, in: The Oxford Handbook of the Incas. Oxford University Press, New York.

Hastorf, C.A., 2017. The Social Archaeology of Food: Thinking about Eating from Prehistory to the Present. Cambridge University Press, New York.

https://doi.org/10.1017/9781316597590

Hastorf, C.A., 2001. Agricultural Production and Consumption, in: D'Altroy, T.N., Hastorf, C.A. (Eds.), Empire and Domestic Economy. Kluwer Academic Publishers, New York, pp. 155178.

Hastorf, C.A., 1993. Agriculture and the Onset of Political Inequality before the Inka. Cambridge University, Cambridge.

Hastorf, C.A., 1991. Gender, Space, and Food in Prehistory, in: Gero, J.M., Conkey, M.W.

(Eds.), Engendering Archaeology: Women and Prehistory. Basil Blackwell, Cambridge, MA, pp. 132-159.

Hastorf, C.A., Johannessen, S., 1993. Pre-Hispanic Political Change and the Role of Maize in the Central Andes of Peru. American Anthropologist 95, 115-138.

Howson, J.E., 1990. Social relations and material culture: A critique of the archaeology of plantation slavery. Historical Archaeology 24, 78-91.

Hu, D., 2019. Making space under the Inca: a space syntax analysis of a mitmaq settlement in Vilcas Huamán Province, Peru. Antiquity 1-19. https://doi.org/10.15184/aqy.2019.82

Hu, D., 2016. Labor under the Sun and the Son: Landscapes of Control and Resistance at Inka and Spanish Colonial Pomacocha, Ayacucho, Peru.

Hu, D., Shackley, M.S., 2018. ED-XRF analysis of obsidian artifacts from Yanawilka, a settlement of transplanted laborers (mitmaqkuna), and implications for Inca imperialism. Journal of Archaeological Science: Reports 18, 213-221.

Jennings, J., Duke, G., 2018. Making the Typical Exceptional: the elevation of Inca cuisine, in: Alconini, S., Covey, R.A. (Eds.), The Oxford Handbook of the Incas. Oxford University Press, New York, pp. 303-322.

Kennedy, S.A., Quave, K.E., 2019. Identificando contextos domésticos Inka por medio de microartefactos: el sitio de Cheqoq (Maras, Cuzco). Qillqana: Revista arqueológica del Cusco 1, 42-63.

Klaus, H.D., Tam Chang, M.E., 2009. Surviving Contact: Biological Transformation, Burial, and Ethnogenesis in the Colonial Lambayeque Valley, North Coast of Peru, in: Knudson, K.J., 
Hu \& Quave 2020

Stojanowski, C.M. (Eds.), Bioarchaeology and Identity in the Americas. University Press of Florida, Gainesville, pp. 126-152.

Knudson, K.J., Gardella, K.R., Yaeger, J., 2012. Provisioning Inka feasts at Tiwanaku, Bolivia: the geographic origins of camelids in the Pumapunku complex. Journal of Archaeological Science 39, 479-491.

Kosiba, S., Bauer, A.M., 2013. Mapping the Political Landscape: Toward a GIS Analysis of Environmental and Social Difference. Journal of Archaeological Method and Theory 20, 61101.

Las Casas, B. de, 1948. De las antiguas gentes del Peru: capítulos de la Apologética historia sumaria antes del año de 1555. Librería e Imprenta D. Miranda, Lima, Peru.

Lorandi, A.M., 1984. Soñocamayoc: Los olleros del Inka en los centros manufactureros del Tucumán. Revista del Museo de la Plata, Sección Antropología 7, 303-327.

Matthews, C.N., Leone, M.P., Jordan, K.A., 2002. The political economy of archaeological cultures: Marxism and American historical archaeology. Journal of Social Archaeology 2, 109-134. https://doi.org/10.1177/1469605302002001599

McGuire, R.H., Reckner, P., 2002. The unromantic West: Labor, capital, and struggle. Historical Archaeology 36, 44-58.

Miller, P.D., Tilley, P.C., 1984. Ideology, power and prehistory: an introduction, in: Ideology, Power and Prehistory. Cambridge University Press, New York, pp. 1-16.

Moore, J.D., 1989. Pre-Hispanic Beer in Coastal Peru: Technology and Social Context of Prehistoric Production. American Anthropologist 91, 682-695.

Morris, C., 1995. Symbols to Power: Styles and Media in the Inka State, in: Carr, C., Neitzel, J.E. (Eds.), Style, Society, and Person: Archaeological and Ethnological Perspectives. Plenum, New York, pp. 419-433.

Murra, J.V., 1980. The economic organization of the Inca State, Research in economic anthropology, 1. JAI Press, Greenwich, CT.

Murra, J.V., 1962. Cloth and Its Functions in the Inca State. American Anthropologist 64, 710728.

Nair, S., 2015. At Home with the Sapa Inca: Architecture, Space, and Legacy at Chinchero. University of Texas Press, Austin.

Niles, S.A., 2004. The nature of Inca royal estates, in: Burger, R.L., Salazar, L.C. (Eds.), Machu Picchu: Unveiling the Mystery of the Incas. Yale University Press, New Haven, pp. 49-68.

Niles, S.A., 1999. The Shape of Inca History: Narrative and Architecture in an Andean Empire. University of lowa, lowa City.

O'Toole, R.S., 2012. Bound Lives: Africans, Indians, and the Making of Race in Colonial Peru. University of Pittsburgh Press. 
Hu \& Quave 2020

Owen, B., 2001. The Economy of Metal and Shell Wealth Goods, in: D'Altroy, T.N., Hastorf, C.A. (Eds.), Empire and Domestic Economy. Kluwer Academic/Plenum, New York, pp. 265-293.

Piel, J., 2014. Capitalismo agrario en el Perú. Institut français d'études andines.

Pizarro, P., 1891. Relación del descubrimiento y conquista del Perú, in: Biblioteca Peruana, Primera Serie, Tomo I. Editores Técnicos Asociados, Lima, pp. 439-586.

Polo de Ondegardo, J. de, 1873. A report by Polo de Ondegardo on the lineage of the Yncas, and how they extended their conquests, in: Markham, C.R. (Ed. \& tran.), Narratives of the Rites and Laws of the Yncas. Hakluyt Society, London, pp. 151-172.

Quave, K., 2018. Royal Estates and Imperial Centers in the Cuzco Region, in: Alconini, S., Covey, A. (Eds.), The Oxford Handbook of the Incas. Oxford University Press, New York, pp. 101-118.

Quave, K.E., 2017. Imperial-style ceramic production on a royal estate in the Inka heartland (Cuzco, Peru). Latin American Antiquity 28, 599-608.

Quave, K.E., 2012. Labor and Domestic Economy on the Royal Estate in the Inka Imperial Heartland (Maras, Cuzco, Peru). Southern Methodist University, Dallas.

Quave, K.E., Covey, R.A., 2015. The Material Remains of Inka Power among Imperial Heartland Communities. Tribus Special Edition, 110-127.

Quave, K.E., Covey, R.A., Durand Cáceres, K.X., 2018. Archaeological Investigations at Yunkaray (Cuzco, Peru): Reconstructing the Rise and Fall of an Early Inca Rival (A.D. 1050-1450). Journal of Field Archaeology 43, 332-343.

Quave, K.E., Kennedy, S.A., Alan Covey, R., 2019. Rural Cuzco before and after Inka Imperial Conquest: Foodways, Status, and Identity (Maras, Peru). Int J Histor Archaeol 23, 868892. https://doi.org/10.1007/s10761-018-0483-0

Quave, K.E., Pilco Vargas, R., Pierce Terry, S., 2013. Las tierras reales del inca como economía noble: viviendas y obras de Cheqoq (Maras, Cuzco), in: Kurin, D.S., Gómez Choque, E. (Eds.), Investigaciones Arqueológicas y Antropológicas En Los Andes SudCentrales: Historia, Cultura y Sociedad. Fondo Editorial de la Dirección de Investigación, Creación Intelectual y Artística Universidad Nacional José María Arguedas, Andahuaylas, Apurímac, Peru, pp. 110-145.

Quichua, D., 2013. Los pueblos de la cuenca de Qaracha (XV-XVII) (Tesis para optar el título profesional de Licenciado en Historia). Universidad Nacional de San Cristóbal de Huamanga, Huamanga, Ayacucho, Perú.

Robinson, C.J., 2000. Black Marxism, 2nd edition. University of North Carolina Press, Chapel Hill.

Rostworowski, M., 1999. History of the Inca Realm. Cambridge University, Cambridge. 
Rostworowski, M., 1970. El repartimiento de Doña Beatriz Coya en el Valle de Yucay. Historia y Cultura 4, 153-267.

Rowe, J.H., 1982. Inca Policies and Institutions Relating to the Cultural Unification of the Empire, in: Collier, G.A., Rosaldo, R., Wirth, J.D. (Eds.), The Inca and Aztec States, 14001800. Academic Press, New York, pp. 93-118.

Rowe, J.H., 1945. Absolute chronology in the Andean area. American Antiquity 10, 265-284.

Rowe, J.H., 1944. An Introduction to the Archaeology of Cuzco. Papers of the Peabody Museum of Anthropology and Ethnology 27.

Sabloff, P.L.W., 2019. The Political Agency of Royal Women: A Comparative Analysis of Eight Premodern States According to Societal Rules and Roles. Journal of Archaeological Research. https://doi.org/10.1007/s10814-019-09131-y

Sandefur, E.C., 2001. Animal Husbandry and Meat Consumption, in: D'Altroy, T.N., Hastorf, C.A. (Eds.), Empire and Domestic Economy, Interdisciplinary Contributions to Archaeology. Kluwer Academic Publishers, New York, pp. 179-202.

Sarmiento de Gamboa, P., 2010. History of the Incas. Ashgate, Farnham, Surrey, Burlington, VT.

Scott, J.C., 2017. Against the grain: a deep history of the earliest states, Yale Agrarian Studies series. Yale University Press, New Haven.

Scott, J.C., 2009. The art of not being governed: an anarchist history of upland Southeast Asia. Yale University Press, New Haven.

Scott, J.C., 1985. Weapons of the Weak: Everyday Forms of Peasant Resistance. Yale University Press, New Haven.

Segalini, L., 2017. ¿"Incas de privilegio"? La probanza de Sancho Usca Paucar y Alonso Auca Puma, caciques principales de Maras y Mullaca (4-12 de mayo de 1569). Revista Andina $55,9-71$.

Sironi, O., 2019. Mining Ways of Life in the Southern Andes: Historical Anthropological Archaeology in Mendoza, Argentina. Int J Histor Archaeol 23, 153-171. https://doi.org/10.1007/s10761-018-0460-7

Smith, M.E., 2019. Quality of Life and Prosperity in Ancient Households and Communities, in: Isendahl, C., Stump, D. (Eds.), The Oxford Handbook of Historical Ecology and Applied Archaeology. Oxford University Press, Oxford.

Smith, M.E., 1987. Household Possessions and Wealth in Agrarian States: Implications for Archaeology. Journal of Anthropological Archaeology 6, 297-335.

Spurling, G.E., 1992. The organization of craft production in the Inka state: The potters and weavers of Milliraya. Cornell University, Ithaca. 
Hu \& Quave 2020

Stark, B.L., 1985. Archaeological Identification of Pottery-Production Locations:

Ethnoarchaeological and Archaeological Data in Mesoamerica, in: Nelson, B.A. (Ed.), Decoding Prehistoric Ceramics, Center for Archaeological Investigations. Southern Illinois University Press, Carbondale, IL, pp. 158-194.

Tilly, C., 1985. War-Making and State-Making as Organized Crime, in: Evans, P., Rueschemeyer, D., Skocpol, T. (Eds.), Bringing the State Back In. Cambridge University Press, Cambridge, pp. 169-191.

Toledo, F. de, 1940. Información comenzada en el Valle de Yucay, junio 2 - septiembre 6 de 1571, in: Levillier, R. (Ed.), Don Francisco de Toledo, Supremo Organizador Del Perú: Su Vida, Su Obra (1515-1582). Tomo II: Sus Informaciones Sobre Los Incas (1570-1572). Espasa-Calpe, Buenos Aires, pp. 122-177.

Toledo, F. de, 1882. Informaciones acerca del Señorío y Gobierno de los Ingas, hechas, por mandado de Don Francisco de Toledo, Virey del Perú 1570-1572, in: Jiménez de la Espada, M. (Ed.), Memorias Antiguas Historiales y Politicas Del Perú. Imprenta de Miguel Ginesta, Madrid, España, pp. 177-259.

Tutino, J., 2011. Making a New World. Duke University Press, Durham.

Valcárcel, L., 1935. Los trabajos arqueológicos en el Departamento del Cusco, Sajsawaman redescubierto, III-IV. Revista del Museo Nacional 4, 1-24, 161-203.

Valcárcel, L., 1934. Los trabajos arqueológicos del Cusco, Sajsawaman redescubierto, I-II. Revista del Museo Nacional 3, 3-36, 211-233.

Villanueva Urteaga, H., 1970. Documentos sobre Yucay, siglo XVI. Revista del Archivo Histórico del Cuzco 13, 1-148.

Villar Córdova, S., 1966. La institución del yanacona en el incanato. Universidad Nacional Mayor de San Marcos, Facultad de Letras y Ciencias Humanas, Departamento de Historia, Lima.

Voss, B.L., 2008. The Archaeology of Ethnogenesis: Race, Sexuality, and Identity in Colonial San Francisco. University of California Press, Berkeley.

Woolf, G., 2012. Rome: An Empire's Story. Oxford University Press, USA.

Woolf, G., 2000. Becoming Roman: The Origins of Provincial Civilization in Gaul. Cambridge University Press.

Woolf, G., 1997. Beyond Romans and natives. World Archaeology 28, 339-350.

Yacobaccio, H.D., Escola, P.S., Lazzari, M., Pereyra, F.X., 2002. Long-distance obsidian traffic in Northwestern Argentina, in: Geochemical Evidence for Long Distance Exchange. Bergin and Garvey, Westport, CT, pp. 167-203.

Yacobaccio, H.D., Escola, P.S., Pereyra, F.X., Lazzari, M., Glascock, M.D., 2004. Quest for ancient routes: obsidian sourcing research in Northwestern Argentina. Journal of Archaeological Science 31, 193-204. https://doi.org/10.1016/j.jas.2003.08.001 
Hu \& Quave 2020

Yaya, I., 2015. Sovereign Bodies: Ancestor Cult and State Legitimacy among the Incas. History \& Anthropology 26, 639-660. https://doi.org/10.1080/02757206.2015.1055330

Yoffee, N., 2005. Myths of the Archaic State: Evolution of the Earliest Cities, States, and Civilizations. Cambridge University Press. 